\title{
Durabilidad del hormigón armado expuesto a condiciones agresivas
}

\section{Durability of reinforced concrete exposed to aggressive conditions}

\author{
A. M. Aguirre(*), R. Mejía de Gutiérrez ${ }^{(*)}$
}

Recepción/Received: 7-I-13

Aceptación/Accepted: 21-I-13

\section{RESUMEN}

El hormigón armado se ha convertido en el material más utilizado a nivel mundial en el sector de la construcción. La combinación de las altas prestaciones a resistencia a la compresión que ofrece el hormigón y las excelentes propiedades mecánicas del acero lo hacen el material compuesto ideal para aplicaciones estructurales. Sin embargo, uno de los mayores problemas que afecta la vida útil del hormigón es la corrosión del acero de refuerzo, la cual se presenta cuando el hormigón se encuentra expuesto a ambientes agresivos, en especial frente a la exposición a iones cloruros y/o dióxido de carbono. Este trabajo revisa el estado del conocimiento con respecto a la durabilidad del hormigón enfatizando en los fenómenos que afectan su durabilidad y generan la corrosión del acero de refuerzo, adicionalmente se incluyen los métodos de prevención y control que se han desarrollado para mitigar el problema, en particular los relacionados con las técnicas electroquímicas de prevención y rehabilitación.

Palabras clave: hormigón armado; corrosión del acero; adiciones minerales; técnicas electroquímicas de rehabilitación.

\begin{abstract}
Reinforced concrete is the most widely used construction material in the world. The combination of high compressive strength, afforded by concrete and, and the excellent mechanical properties that characterise steel make it an ideal composite for all manner of structures. One of the main weaknesses of this material, however, is that when the concrete is exposed to aggressive environments, in particular high concentrations of chloride ions or carbon dioxide, reinforcing steel corrodes, shortening service life. This article reviews the state of the art on concrete durability, along with the conditions that affect its useful life by inducing reinforcing steel corrosion. It also discusses the prevention and control methods, in particular electrochemical prevention and rehabilitation techniques, that have been developed to mitigate the problem.
\end{abstract}

Keywords: reinforced concrete; steel corrosion; mineral additions; electrochemical rehabilitation.

(*) Universidad del Valle, (Cali, Colombia).

Persona de contacto/Corresponding author: ruby.mejia@correounivalle.edu.co 


\section{INTRODUCCIÓN}

El hormigón ha sido uno de los materiales más utilizados en el sector de la construcción a través de la historia por su versatilidad y bajo costo $(1,2)$. En cuanto a sus características, es un material cerámico que soporta esfuerzos a compresión; sin embargo, es susceptible a fisurarse a otros tipos de solicitaciones mecánicas tales como flexión, tracción, torsión, cortante, entre otros. De ahí surgió el material compuesto, el hormigón armado, combinación de hormigón y acero estructural, utilizado ampliamente en construcción de puentes, edificios, rascacielos, túneles, entre otros. Uno de los factores importantes del hormigón, además de sus propiedades mecánicas, es su durabilidad, la cual se puede asociar con la vida útil en servicio de una estructura una vez es expuesta a determinadas condiciones o ambientes $(3,4)$. En particular, la corrosión del acero de refuerzo ha sido identificada como el principal problema en el hormigón armado (5). Este trabajo presenta los principales procesos de deterioro del hormigón incluyendo aquellos que contribuyen a la corrosión del acero, y los métodos de prevención y control, tales como el uso de inhibidores y recubrimientos, la incorporación de adiciones inorgánicas y las técnicas electroquímicas utilizadas para extender su vida útil.

\section{FENÓMENOS QUE AFECTAN LA DURABILIDAD DEL HORMIGÓN}

El hormigón al estar expuesto a ambientes agresivos puede presentar procesos de deterioro. Estos pueden ser clasificados como: físicos, causados por la exposición a cambios ambientales extremos tales como ciclos de hielo/deshielo o cambios artificiales como la exposición al fuego; químicos, causados por ataques por ácidos y/o sulfatos, agua, o reacción álcali-árido; biológicas y estructurales (presencia de bacterias, sobrecargas, ciclos de cargas, etc.) $(6,7)$. La corrosión del acero de refuerzo está ligada con los procesos de deterioro del hormigón, debido a que conduce al agrietamiento y delaminación del material y además reduce su adhesión al refuerzo. Algunos de los fenómenos mencionados se presentan a continuación.

\subsection{Ciclos de hielo/deshielo}

Cuando la temperatura ambiental disminuye a valores por debajo de $0{ }^{\circ} \mathrm{C}$, el agua que se encuentra contenida en los poros del hormigón se congela, causando un incremento en volumen del orden del $9 \%$. Como consecuencia, se presentan esfuerzos de tensión, que originan grietas y delaminación del hormigón, o en casos más graves, una completa desintegración (3).

\section{INTRODUCTION}

Versatility and low cost have made concrete one of the world's most popular construction materials $(1,2)$. This ceramic material is characterised by high compressive strength, although it is prone to cracking under other types of mechanical stress such as bending and tensile forces, torque and shear. That weakness led to the advent of reinforced concrete, a combination of concrete and structural steel widely used to build bridges, buildings in general and skyscrapers in particular, tunnels and a host of other structures. One of the most important features of concrete, in addition to its mechanical properties, is its durability, which is associated with the inservice life of structures exposed to certain conditions or environments (3, 4). More specifically, reinforcing steel corrosion has been identified as the main weakness of reinforced concrete (5). This paper discusses the main types of concrete deterioration, including the processes that contribute to steel corrosion, and the respective prevention and control methods, such as the use of inhibitors and coatings, inorganic additions and electrochemical techniques to extend its service life.

\section{FACTORS THAT AFFECT CONCRETE DURABILITY}

Concrete may deteriorate when exposed to aggressive environments. These may be classified as physical, resulting from exposure to extreme environmental changes such as freeze/thaw or fire; chemical, caused by acid or sulfate attack, water or the alkali-aggregate reaction; biological, including the presence of bacteria; or structural, i.e., live loads or load cycles $(6,7)$. Reinforcing steel corrosion is related to concrete deterioration inasmuch as the latter induces cracking and scaling, while also weakening the concrete-steel bond. Some of these factors are discussed below.

\subsection{Freeze-thaw cycles}

When the outdoor temperature drops to below $0^{\circ} \mathrm{C}$, the water in the concrete pores freezes, increasing its volume by around 9\%. This induces tensile stress, generating concrete cracking and scaling or, in extreme cases, full-fledged disintegration (3). 
La acción del congelamiento ocurre principalmente en el agua que se encuentra en los poros capilares, de hecho, no afecta los espacios interlaminares en el gel C-S-H debido a su tamaño reducido, al menos que la temperatura esté por debajo de $-35^{\circ} \mathrm{C}$ (7). Por otra parte, la presencia de espacios con aire pueden reducir el efecto causado por la formación de hielo en el hormigón.

Se han considerado los siguientes mecanismos para explicar este fenomeno: presión hidráulica, propuesta por Powers, que explica que el agua congelada dentro del poro capilar genera una resistencia hidráulica al paso del agua que aún se encuentra en estado líquido, generando una presión, la cual solo se libera si hay poros vecinos libres; presión osmótica, al ocurrir el congelamiento en los poros capilares existe una diferencia de concentración entre el hielo y el agua remanente, generando el flujo del agua desde los espacios interlaminares del gel hacia los poros capilares, incrementando así la presión interna; y por último sobrepresión del hielo, desde poros pequeños el agua se transporta hacia poros ya congelados, generando un incremento del volumen de hielo y consecuentemente la presión $(7,8)$.

Los factores que contribuyen a la resistencia del hormigón al congelamiento son la relación agua/cemento, el grado de saturación de los poros del hormigón, el curado, la proporción de aire incorporado y los áridos. Así, para mejorar la resistencia se debe tener en cuenta una baja relación agua/cemento, un curado prolongado y un porcentaje de aire incorporado. De acuerdo con la Norma Europea EN 206 (9) se definen cuatro clases de severidad del ataque (XF1 hasta XF4), tal como se indica en la Tabla 1, y, acorde a estas clases, la misma norma define los valores límites de la composición y propiedades del hormigón (Tabla 2).
Freezing affects the water in capillary pores but not the tiny interstices in C-S-H gel except at temperatures of under $-35^{\circ} \mathrm{C}$ (7). The presence of entrained air, in turn, can reduce the effect of ice formation in concrete.

The mechanisms suggested to explain the stress development include: hydraulic pressure, proposed by Powers, according to which the water frozen in capillary pores resists the flow of water still in the liquid state, generating pressure that is only released if neighbouring pores are empty; osmotic pressure, whereby freezing in capillary pores generates differences in concentration between the ice and remaining water, inducing the flow of water from gel interstices outward into capillary pores and raising the internal pressure; and lastly ice-induced excess pressure, with water migrating from smaller pores to frozen pores, raising ice volume and consequently pressure $(7,8)$.

Factors that contribute to concrete freeze resistance include the water/cement ratio, the degree of concrete pore saturation, curing, the air content, and the aggregate. Resistance can be enhanced with a low water/ cement ratio, extended curing and a certain percentage of air. The four exposure classes defined in European standard EN 206 (9) (XF1 to XF4) are listed in Table 1, while the respective requirements for concrete composition and properties are given in Table 2.

Tabla 1 / Table 1

Clase de exposición para ataque de hielo/deshielo - Norma EN206 (9).

European standard EN206 (9) freeze-thaw attack exposure classes.

\begin{tabular}{|c|c|c|}
\hline Clase / Class & Descripción / Description & Ejemplos / Example \\
\hline $\mathrm{XF1}$ & $\begin{array}{c}\text { Saturación de agua moderada, sin agentes } \\
\text { de deshielo / Moderate water saturation, no } \\
\text { de-icing agents }\end{array}$ & $\begin{array}{l}\text { Superficies verticales de hormigón expuestas a la lluvia y a la helada / } \\
\text { Vertical concrete surfaces exposed to rain and frost }\end{array}$ \\
\hline $\mathrm{XF2}$ & $\begin{array}{c}\text { Saturación de agua moderada, con agentes } \\
\text { de deshielo / Moderate water saturation with } \\
\text { de-icing agents }\end{array}$ & $\begin{array}{l}\text { Superficies verticales de hormigón de estructuras de carreteras expuestas a la } \\
\text { helada y a al aire que transporta a los agentes de deshielo / Vertical concrete } \\
\text { surfaces of road structures exposed to frost and air-borne de-icing agents }\end{array}$ \\
\hline XF3 & $\begin{array}{l}\text { Saturación de agua elevada, sin agentes de } \\
\text { deshielo / High water saturation, no de-icing } \\
\text { agents }\end{array}$ & $\begin{array}{l}\text { Superficies horizontales de hormigón expuestas a la lluvia y a la helada / } \\
\text { Horizontal concrete surfaces exposed to rain and frost }\end{array}$ \\
\hline XF4 & $\begin{array}{l}\text { Saturación de agua elevada, con agentes de } \\
\text { deshielo / High water saturation with de-icing } \\
\text { agents }\end{array}$ & $\begin{array}{c}\text { Carreteras y puentes expuestos a agentes de deshielo y superficies verticales } \\
\text { expuestas directamente a salpicaduras de agentes de deshielo y a la helada. } \\
\text { Zonas de estructuras marinas sometidas a salpicaduras y a la helada / Roads } \\
\text { and bridges exposed to de-icing agents and vertical surfaces directly exposed to } \\
\text { frost and spray-borne de-icing agents; marine structures exposed to sea spray } \\
\text { and frost }\end{array}$ \\
\hline
\end{tabular}


Tabla 2 / Table 2

Valores límites recomendados para el hormigón según EN206 (9) (hielo-deshielo). EN206 (9) specifications for concrete exposed to freeze-thaw events.

\begin{tabular}{|c|c|c|c|c|}
\hline Clase / Class & $\begin{array}{c}\text { Máxima relación } \\
\text { a/c / } \\
\text { Maximum w/c ratio }\end{array}$ & $\begin{array}{c}\text { Clase de resistencia mínima } \\
\text { / Minimum strength class }\end{array}$ & $\begin{array}{c}\text { Contenido mínimo de } \\
\text { cemento (kg/m } \mathbf{3}) \text { / Minimum } \\
\text { cement content }\end{array}$ & $\begin{array}{c}\text { Contenido mínimo de } \\
\text { aire (\%) / Minimum air } \\
\text { content (\%) }\end{array}$ \\
\hline XF1 & 0.55 & $\mathrm{C} 30 / 37$ & 300 & - \\
\hline XF2 & 0.55 & $\mathrm{C} 25 / 30$ & 300 & $4.0^{*}$ \\
\hline XF3 & 0.55 & $\mathrm{C} 30 / 37$ & 320 & $4.0^{*}$ \\
\hline XF4 & 0.55 & $\mathrm{C} 30 / 37$ & 340 & $4.0^{*}$ \\
\hline $\begin{array}{c}\text { Otros requisitos / } \\
\text { Other requisites }\end{array}$ & \multicolumn{2}{|c|}{$\begin{array}{c}\text { Áridos conformes con prEN 12620:2000 suficientemente resistentes al hielo/deshielo } \\
\text { / prEN 12620:2000-compliant aggregates with sufficient freeze-thaw resistance }\end{array}$} \\
\hline
\end{tabular}

* Si el hormigón no contuviese aire incluido, su prestación debería medirse de acuerdo con un método de ensayo apropiado, en comparación con un hormigón de resistencia probada al hielo/deshielo en la clase de exposición correspondiente / If the concrete contains no air, its performance should be measured with a suitable test method, comparing the results to the findings for a proven freeze-thaw-resistant concrete in the respective exposure class.

Una forma de determinar la resistencia al hielo/deshielo se describe en la norma ASTM C666 (10), en la cual la durabilidad del hormigón se mide a través de la reducción del módulo de elasticidad dinámico. Esta norma permite realizar el ensayo utilizando dos métodos: el Procedimiento $A$, congelamiento y deshielo en agua; o el Procedimiento $B$, congelamiento en aire y deshielo en agua (11).

\subsection{Ataque por sulfatos}

Este fenómeno se genera cuando el hormigón se encuentra expuesto a aguas subterráneas, lagos, pozos o suelos que contienen iones sulfatos. Estos pueden penetrar el hormigón y reaccionar con los componentes de la matriz cementicia causando reacciones químicas expansivas.

El ataque por sulfatos se manifiesta con una pérdida progresiva de la resistencia de la pasta de cemento debido a la pérdida de cohesión entre los productos de hidratación. Además, los productos expansivos generan agrietamientos en el hormigón; cuando esto sucede la permeabilidad del hormigón incrementa, permitiendo así la entrada de otros agentes que pueden acelerar el deterioro $(6,7)$.

El hidróxido de calcio y los aluminosilicatos presentes en el cemento son los más susceptibles al ataque por sulfatos. Los iones sulfatos pueden reaccionar con el hidróxido de calcio para formar yeso según [1]:
One way to determine freeze/thaw resistance is set out in ASTM standard C666 (10), in which concrete durability is measured in terms of the decline in the dynamic modulus of elasticity. This standard recommends two methods for running the test: procedure $A$, freezing and thawing with the specimen immersed in water, and procedure $B$, air freezing and underwater thawing (11).

\subsection{Sulfate attack}

This type of attack occurs when concrete is exposed to sulfate ion-containing groundwater, lakes, wells or soils. These ions can penetrate the concrete and react with the components of the cementitious matrix, inducing expansive chemical reactions.

The symptoms of sulfate attack are a gradual loss of cement paste strength due to a decline in the cohesion among the hydration products. Moreover, expansive products can induce concrete cracking, raising the permeability of the material and favouring the ingress of other agents that may accelerate decay $(6,7)$.

The calcium hydroxide and aluminium silicates present in cement are the compounds most susceptible to sulfate attack. The sulfate ions may react with calcium hydroxide to form gypsum, as in [1]:

$$
\mathrm{Ca}(\mathrm{OH})_{2}+\mathrm{SO}_{4}{ }^{2-}+2 \cdot \mathrm{H}_{2} \mathrm{O} \rightarrow \mathrm{CaSO}_{4} \cdot 2 \mathrm{H}_{2} \mathrm{O}+2 \mathrm{OH}^{-}
$$

y con los aluminatos cálcicos para formar etringita, seand with calcium aluminates to form ettringite as in [2]: gún [2]:

$$
\mathrm{C}_{3} \mathrm{~A}+3 \mathrm{CaSO}_{4}+32 \mathrm{H}_{2} \mathrm{O} \rightarrow 3 \mathrm{CaO} \cdot \mathrm{Al}_{2} \mathrm{O}_{3} \cdot 3 \mathrm{CaSO}_{4} \cdot 32 \mathrm{H}_{2} \mathrm{O}
$$

Esta última reacción es más perjudicial, ya que produce los efectos expansivos en el hormigón; sin embargo, el mecanismo por el cual la etringita causa expansión es
The latter reaction is more harmful, for it prompts concrete expansion, although no consensus has been reached about the mechanism involved in that process 
aún controvertido (6). Debido a esta reacción los cementos con alto contenido de $\mathrm{C}_{3} \mathrm{~A}$, del orden del $8 \%$ o más, no se recomiendan para ser usados en ambientes que puedan estar contaminados de sulfatos (12). La norma europea EN 197-1:2011 incorpora un nuevo requisito que deben cumplir los clínkeres con los que se van a fabricar los cementos resistentes a los sulfatos, se trata del límite superior del contenido de $\mathrm{C}_{3} \mathrm{~A}$, así para el CEM I: $0 \%, 3 \%$ o $5 \%$ según corresponda, para el CEM IV/A y CEM IV/B: $9 \%$; cabe anotar que para el CEM III no se plantea este requisito (13).

La severidad del ataque depende principalmente de la concentración de los iones sulfatos en el suelo o agua que están contacto con el hormigón. Además las soluciones de sulfatos, tales como sulfato de magnesio, generan un ataque más agresivo, ya que los productos de la reacción son yeso e hidróxido de magnesio, este último es insoluble y reduce la alcalinidad del hormigón (6); el sulfato de amonio por su parte produce gas amoniaco (7).

Bajo condiciones particulares - presencia de $\mathrm{CO}_{2}$, alta humedad relativa (>95\%) y bajas temperaturas- los sulfatos pueden reaccionar con el hidróxido de calcio y el silicato cálcico hidratado (C-S-H) y producir taumasita. Este fenómeno genera una pérdida completa de la resistencia del hormigón (7). En ambientes altamente agresivos, como en pozos gasíferos a presión y temperaturas elevadas, se observan sobre el cemento acciones agresivas combinadas de gases agrios $\left(\mathrm{CO}_{2}\right.$ y $\left.\mathrm{H}_{2} \mathrm{~S}\right)$ e iones sulfatos, cloruros y magnesio, en particular la lixiviación de algunos de sus componentes y la menor formación de silicatos (14).

Por lo anterior, uno de los factores que influye para prevenir el ataque a sulfatos es la calidad del hormigón. Una baja relación agua/cemento reduce la permeabilidad y dificulta el ingreso de los iones sulfato; el uso de adiciones puzolánicas (cenizas volantes, escorias, metacaolín, entre otras) aumenta la resistencia a sulfatos; al respecto se han realizado diversas investigaciones (15-20).

De acuerdo con la Norma Europea EN 206 (9) se definen tres clases de severidad al ataque químico (XA1, XA2, XA3), tal como se aprecia en la Tabla 3. Los valores recomendados de la dosificación y propiedades del hormigón para cada caso y los valores límites de sulfatos en suelos naturales y aguas subterráneas en contacto con el hormigón son incluidos en las Tablas 4 y 5.

Una de las formas visibles del deterioro por ataque de sulfatos son las expansiones volumétricas, al respecto las normas ASTM C1012 (21) y ASTM C1157 (22) especifican los métodos de medición y los límites de expansión en cementos hidráulicos, respectivamente.
(6). In light of the foregoing, cements with a high $C_{3} A$ content, on the order of $8 \%$ or higher, are not recommended for sulfate-polluted environments (12). The new 2011 version of European standard EN 197 (EN 1971:2011) sets $C_{3} A$ content ceilings for clinkers intended for use in sulfate-resistant cements, as follows: for CEM I: 0,3 or 5\%, as appropriate; for CEM IV/A and CEM IV/B: 9\%. No ceiling is established for CEM III (13).

The severity of the attack depends primarily on the sulfate ion concentration in the soil or water surrounding the concrete. Solutions such as magnesium sulfate are more aggressive, for the reaction products are gypsum and magnesium hydroxide, which is insoluble and lowers concrete alkalinity (6); ammonium sulfate, in turn, produces ammonia gas (7).

Under specific conditions (presence of $\mathrm{CO}_{2}$, high relative humidity (>95\%) and low temperatures), sulfates may react with calcium hydroxide and calcium silicate hydrate (C-S-H) to form thaumasite. This series of events lowers concrete strength drastically (7). In highly aggressive environments, such as gas wells where pressure and temperature are high, the combined aggressive action of acid gases $\left(\mathrm{CO}_{2}\right.$ and $\left.\mathrm{H}_{2} \mathrm{~S}\right)$ and sulfate, chloride and magnesium ions induces leaching of some cement components and reduces silicate formation (14).

Consequently, concrete quality plays a role in preventing sulfate attack. A low water/cement ratio lessens permeability and hinders sulfate ion ingress; the use of pozzolanic additions (such as fly ash, slag or metakaolin) raises sulfate resistance, as observed in a number of studies (15-20).

European standard EN 206 (9) defines three classes of chemical exposure (XA1,XA2, XA3), listed in Table 3. The recommended dosages and concrete properties for each case and the maximum allowable sulfate levels in natural soils and groundwater in contact with concrete are given in Tables 4 and 5.

One of the more visible forms of sulfate-induced deterioration consists of volumetric expansion. ASTM standards C1012 (21) and C1157 (22) recommend measuring methods and expansion ceilings for hydraulic cements, respectively. 
Tabla 3 / Table 3

Clase de exposición para ataque químico de acuerdo a la norma EN206. EN206 (9) chemical exposure classes.

\begin{tabular}{|c|c|}
\hline Clase / Class & Descripción / Description \\
\hline XA1 & $\begin{array}{c}\text { Ambiente químico ligeramente agresivo / } \\
\text { Slightly aggressive chemical environment }\end{array}$ \\
\hline XA2 & $\begin{array}{c}\text { Ambiente químico moderadamente agresivo / } \\
\text { Moderately aggressive chemical environment }\end{array}$ \\
\hline XA3 & Ambiente químico altamente agresivo / \\
Highly aggressive chemical environment
\end{tabular}

Tabla 4 / Table 4

Valores límites recomendados para el hormigón según EN206 (9) (ataque químico). EN206 (9) specifications for concretes exposed to chemical attack.

\begin{tabular}{|c|c|c|c|}
\hline Clase / Class & $\begin{array}{c}\text { Máxima relación a/c / } \\
\text { Maximum w/c ratio }\end{array}$ & $\begin{array}{c}\text { Resistencia mínima / } \\
\text { Minimum strength }\end{array}$ & $\begin{array}{c}\text { Contenido mínimo de cemento (kg/m }{ }^{3} \text { / } \\
\text { Minimum cement content }\end{array}$ \\
\hline XA1 & 0.55 & $\mathrm{C} 30 / 37$ & 300 \\
\hline XA2 & 0.5 & $\mathrm{C} 30 / 37$ & 320 \\
\hline XA3 & 0.45 & $\mathrm{C} 35 / 45$ & 360 \\
\hline Otros requisites / Other requisites & \multicolumn{3}{|c|}{ Cemento resistente a sulfatos* / Sulfate resistance* } \\
\hline
\end{tabular}

* Es esencial la utilización de cemento resistente a los sulfatos cuando el contenido de $\mathrm{SO}_{4}{ }^{2-}$ conduzca a clases de exposición XA2 y XA3. En clases de exposición XA2 (y en clase XA1 cuando proceda) deberían utilizarse cementos clasificados como moderada o altamente resistentes, para clasificación XA3 deben ser cementos altamente resistentes a sulfatos. / The use of sulfate-resistant cement is essential for exposure classes XA2 or XA3, as defined by the $\mathrm{SO}_{4}{ }^{2-}$ content. In exposure class XA2 (and class XA1 where appropriate), moderately or highly resistant cements are required. In exposure class XA3, only highly sulfate-resistant cements are suitable.

Tabla 5 / Table 5

Valores límites para clases de exposición - Ataque químico de suelos naturales y aguas subterráneas. Attack by chemicals in natural soil and groundwater - parameter limits by exposure class.

\begin{tabular}{|c|c|c|c|c|}
\hline $\begin{array}{c}\text { Característica química I } \\
\text { Chemical parameter }\end{array}$ & $\begin{array}{l}\text { Método referencia / } \\
\text { Reference standard }\end{array}$ & XA1 & XA2 & XA3 \\
\hline \multicolumn{5}{|c|}{ Aguas subterráneas / Groundwater } \\
\hline $\mathrm{SO}_{4}^{2-}, \mathrm{mg} / \mathrm{l}$ & EN 196-2 & $\geq 200-\leq 600$ & $>600-\leq 3000$ & $>3000 y \leq 6000$ \\
\hline $\mathrm{pH}$ & ISO 4316 & $\leq 6.5-\geq 5.5$ & $<5.5-\geq 4.5$ & $<4.5-\geq 4.0$ \\
\hline Aggressive $\mathrm{CO}_{2}, \mathrm{mg} / \mathrm{l}$ & Pr EN13577 & $\geq 15-\leq 40$ & $>40-\leq 100$ & $>100$ (to saturation) \\
\hline $\mathrm{NH}^{4+}, \mathrm{mg} / \mathrm{l}$ & ISO7150-1 o ISO7150-2 & $\geq 15-\leq 30$ & $>1000-\leq 3000$ & $\begin{array}{c}\quad>3000 \\
\text { (to saturation) }\end{array}$ \\
\hline $\mathrm{Mg}_{2}+, \mathrm{mg} / \mathrm{l}$ & ISO 7980 & $\geq 300-\leq 1000$ & $>30-\leq 60$ & $>60-\leq 100$ \\
\hline \multicolumn{5}{|c|}{ Suelo / Natural Soil } \\
\hline $\mathrm{SO}_{4}^{2-}, \mathrm{mg} / \mathrm{kg}$ & EN 196-2 & $\geq 2000-\leq 3000$ & $>3000-\leq 12000$ & $>12000-\leq 24000$ \\
\hline Acidez / Acidity & DIN 4030-2 & >200 Baumann Gully & \multicolumn{2}{|c|}{$\begin{array}{l}\text { No se da en la práctica / } \\
\text { Of no practical consequence }\end{array}$} \\
\hline
\end{tabular}

\subsection{Reacción álcali-árido}

Algunos tipos de áridos pueden reaccionar químicamente con iones hidroxilos y componentes alcalinos de la pasta del cemento, generando reacciones expansivas, agrietamientos del hormigón, pérdida de resistencia y del módulo elástico $(6,23)$. Estas reacciones se dan principalmente con áridos que contienen ciertas formas amorfas de sílice (reacción álcali-sílice ASR), áridos carbonatados que contienen dolomita y minerales arcillosos (reacción álcali-carbonatado) y áridos que contienen filosilicatos (reacción álcali-silicato). El desarrollo de la reacción álcali-sílice es muy lenta y sus efectos solo se producen a través del tiempo (3). Este tipo de reacción álcali-árido

\subsection{Aggregate-alkali reaction}

Some types of aggregate may react chemically with the hydroxyl ions and alkaline components present in cement, originating expansive reactions, concrete cracking, strength loss and a decline in the modulus of elasticity $(6,23)$. These reactions are found primarily in aggregates containing certain amorphous forms of silica (alkali silica reaction, ASR), carbonated aggregates containing dolomite and clay minerals (alkali-carbonate reaction) and phyllosilicate-bearing aggregates (alkalisilicate reaction). The alkali-silicate reaction proceeds very slowly and its effects appear in the long term only (3). Due to the significant deterioration caused, this type 
representa un problema de deterioro significativo en varios países alrededor del mundo, tales como, Inglaterra, Dinamarca, Noruega, Francia, Bélgica, Holanda, Canadá y Estados Unidos, entre otros (7).

Las condiciones necesarias para que se dé la reacción álcali-árido son: la presencia de álcali $\left(\mathrm{Na}_{2} \mathrm{O}\right.$ y $\left.\mathrm{K}_{2} \mathrm{O}\right)$ en proporción suficiente en el hormigón para que reaccione con los áridos, estos álcalis pueden encontrarse en el cemento, agua o medio de exposición; un árido reactivo; la presencia de humedad en ordenes entre el $80-85 \%$ (estructuras expuestas a lluvias permanentes, hormigones en contacto con terrenos húmedos, presas, etc.); y por último la temperatura, particularmente en el caso de cementos de fraguado rápido que desarrollan calor de hidratación elevado (3). Cabe anotar que el límite máximo de álcalis para el hormigón es de $3 \mathrm{~kg} / \mathrm{m}^{3}$ y para cementos es $0,6 \%$ expresado como $\mathrm{Na}_{2} \mathrm{O}(3,7,24)$.

De los tipos de reacción álcali-árido, la más común y ampliamente estudiada es la reacción álcali-sílice. Aquí los iones hidroxilo causan la destrucción de los enlaces atómicos de los compuestos de silicio, los iones álcali reaccionan con $\mathrm{Si}(\mathrm{OH})_{4}$ y forman un gel $(\mathrm{Na}, \mathrm{K})-\mathrm{Si}-\mathrm{OH}$, en el cual se intercambian $\mathrm{Na}$ y $\mathrm{K}$ por $\mathrm{Ca}$ hasta que el gel se solidifica; posteriormente este absorbe agua hasta expandirse, lo cual genera esfuerzos de tensión dentro del hormigón y conduce al agrietamiento (7).

Desde que la reacción álcali-sílice fue identificada se ha clasificado un gran número de tipos de rocas potencialmente reactivas, algunas rocas son similares pero varían en su reactividad, esta depende de su localización geográfica y su histórica geológica (25). El primer paso para determinar la reactividad del árido es realizar una caracterización petrográfica (ASTM C295) (26) para identificar el tipo de roca. En RILEM AAR-1 (27) se encuentra la lista de los tipos de rocas reactivas y su clasificación por países. Una de las normas para la prueba química de áridos es la ASTM C289 (28).

En general, las adiciones tipo puzolanas ayudan a mitigar este ataque, siendo considerada como más eficiente el humo de sílice para reducir las expansiones de las reacciones álcali-sílice; el porcentaje óptimo de SF recomendado está entre el 8-10\% (25).

La reacción álcali-carbonato no es tan frecuente en comparación a la reacción álcali-sílice. Aquí ocurre la desdolomitización de los áridos, que se refiere fundamentalmente a la reacción del carbonato cálcico y magnésico con la solución alcalina para dar lugar a brucita $\mathrm{Mg}(\mathrm{OH})_{2}$ y a la regeneración de hidróxido alcalino, según [3] y [4], respectivamente. La brucita es un producto insoluble y produce debilitamiento de la unión de cemento-árido $(3,29)$. of alkali-aggregate reaction is an important consideration in a number of countries, including England, Denmark, Norway, France, Belgium, Netherlands, Canada and the United States (7).

The conditions required for the alkali-aggregate reaction are: the presence of a sufficient proportion of alkalis $\left(\mathrm{Na}_{2} \mathrm{O}\right.$ and $\left.\mathrm{K}_{2} \mathrm{O}\right)$ in the concrete (i.e., the cement, water or exposure medium) to react with the aggregate; a reactive aggregate; the presence of relative humidity on the order of $80-85 \%$ (structures exposed to constant rain, concrete in contact with moist soil, dams and similar); and lastly temperature, particularly in the case of rapid-setting cements with high heat of hydration rates (3). The maximum alkali content allowed in concrete is $3 \mathrm{~kg} / \mathrm{m}^{3}$ and in cement $0.6 \%$, expressed as $\mathrm{Na}_{2} \mathrm{O}(3,7,24)$.

The most common and widely studied type of alkaliaggregate reaction is the alkali-silica reaction. Here the hydroxyl ions sever the atomic bonds in silicon compounds and the alkaline ions react with $\mathrm{Si}(\mathrm{OH})_{4}$ to form a $(\mathrm{Na}, \mathrm{K})-\mathrm{Si}-\mathrm{OH}$ gel in which the Ca is replaced by $\mathrm{Na}$ and $K$ until the gel solidifies. This gel subsequently absorbs water and expands, generating tensile stress inside the concrete and concomitant cracking (7).

In the interim since the alkali-silica reaction was identified, a substantial number of potentially reactive rock types have been classified. Some are similar but with varying reactivity, depending on their geographic location and geological history (25). The first step when determining aggregate reactivity is to run a petrographic characterisation (ASTM C295) (26) to identify the rock type. The RILEM AAR-1 (27) contains a list of reactive rock types by country and their classification, while ASTM standard C289 (28) describes a procedure for testing aggregate reactivity.

While all pozzolanic additions mitigate ASR, the expansion induced is controlled most effectively by silica fume. The recommended proportion of SF ranges from 8 to $10 \%$ (25).

The alkali-carbonate reaction differs very little from the alkali-silica reaction. In this case, the aggregates are dedolomitised, with calcium and magnesium carbonate reacting with the alkaline solution to produce brucite $\left(\mathrm{Mg}(\mathrm{OH})_{2}\right)$ and regenerate alkaline hydroxide, as in [3] and [4], respectively. Brucite is insoluble and weakens the cement-aggregate bond $(3,29)$. 


$$
\begin{gathered}
\mathrm{CaMg}\left(\mathrm{CO}_{3}\right)_{2}+2 \mathrm{NaOH} \rightarrow \mathrm{Mg}(\mathrm{OH})_{2}+\mathrm{CaCO}_{3}+\mathrm{Na}_{2} \mathrm{CO}_{3} \\
\mathrm{Na}_{2} \mathrm{CO}_{3}+\mathrm{Ca}(\mathrm{OH})_{2} \rightarrow \mathrm{CaCO}_{3}+2 \mathrm{NaOH}
\end{gathered}
$$

En el caso de las reacciones álcali-sílice, las normas ASTM C1293 (30) y ASTM C227 (31) presentan métodos para la determinación del cambio de la longitud del hormigón debido a ASR y su consecuente expansión.

\section{CORROSIÓN DEL ACERO DE REFUERZO EMBEBIDO EN EL HORMIGÓN}

El hormigón es un material altamente alcalino $(\mathrm{pH}$ entre $12,6$ y 13,8$)$, principalmente debido a los hidróxidos de calcio, sodio y potasio presentes. Bajo estas condiciones de $\mathrm{pH}$, el acero que se encuentra embebido dentro del hormigón forma espontáneamente una capa pasiva, que aunque de pocos nanómetros de espesor presenta una acción protectora (7). Sin embargo, esta película puede ser destruida por agentes agresivos tales como los iones cloruros y/o el $\mathrm{CO}_{2}$, lo que produce una despasivación del acero de refuerzo.

\subsection{Iniciación y propagación de la corrosión}

La vida útil de las estructuras de hormigón armado se ha basado en el modelo de Tuutti, el cual considera dos etapas, la primera corresponde a la etapa de iniciación y la segunda a la etapa de propagación de la corrosión, tal como se aprecia en la Figura $1(3,7,32,33)$.
ASTM standards C1293 (30) and C227 (31) describe methods for determining ASR-induced expansion in concrete specimens.

\section{CORROSION IN CONCRETE-EMBEDDED REINFORCING STEEL}

Concrete is a highly alkaline material ( $\mathrm{pH}$ ranging from 12.6 to 13.8), due primarily to its calcium, sodium and potassium hydroxide content. Under these $\mathrm{pH}$ conditions, the embedded steel spontaneously forms a passive layer which, while only a few nanometers thick, affords it protection (7). This film can be destroyed by aggressive agents such as chloride ions or $\mathrm{CO}_{2}$, however, in a process known as depassivation.

\subsection{Corrosion initiation and progression}

The service life of reinforced concrete structures is based on the Tuutti model, which defines two stages, initiation and progression, as illustrated in Figure 1 (3, $7,32,33)$.

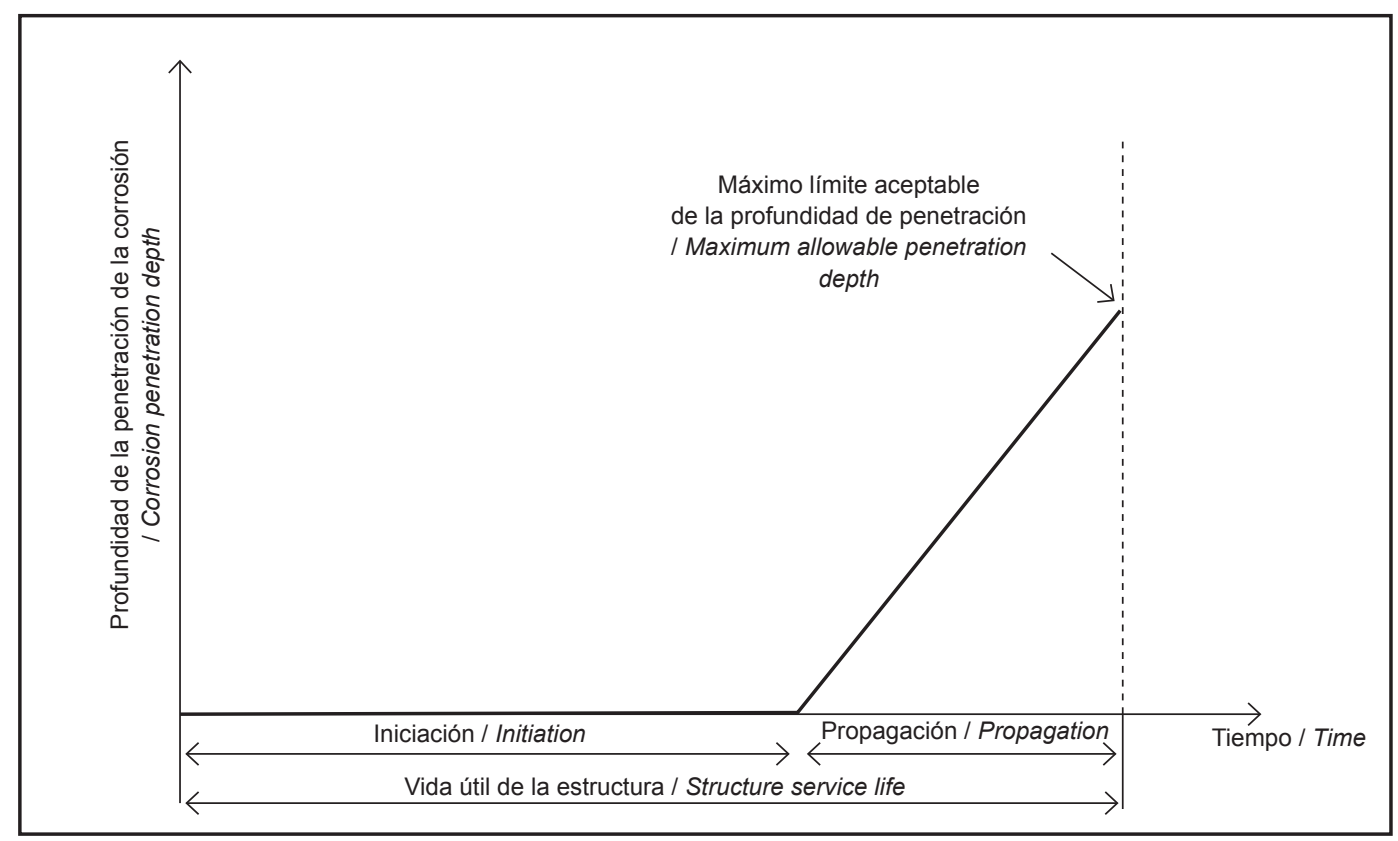

Figura 1. Modelo de Tuutti. Tomado de Bertolini et al. (7).

Figure 1. Tuutti Model. From Bertolini et al. (7). 
Iniciación: en esta etapa los agentes agresivos $\left(\mathrm{CO}_{2} \mathrm{e}\right.$ iones cloruros) ingresan a la matriz cementicia. La duración de esta fase depende de la calidad y profundidad del recubrimiento de hormigón y la velocidad de penetración de los agentes agresivos (32).

Propagación: en esta etapa se da la destrucción de la capa pasiva del acero, y la corrosión ocurrirá únicamente si el agua y oxígeno están presentes en la superficie del refuerzo hasta que se alcanza un nivel inaceptable $(7,32)$.

\subsection{Proceso básico de la corrosión}

La corrosión del acero de refuerzo embebido en hormigón obedece a un proceso electroquímico. Para que se dé lugar a la corrosión se requiere la presencia de zonas anódicas, catódicas y un electrolito para formar una celda de corrosión (5). En esta se da un proceso de óxido-reducción; la zona anódica corresponde al proceso de oxidación, donde hay una pérdida de electrones [5]; a su vez la reacción catódica corresponde al proceso de reducción, donde los electrones producidos en el ánodo se combinan con determinados iones del electrolito, y se produce una ganancia de electrones [6].
Initiation: in this stage the aggressive agents $\left(\mathrm{CO}_{2}\right.$ and chloride ions) penetrate the cementitious matrix. The duration of this phase depends on the quality and depth of the concrete cover and the penetration rate of the aggressive agents (32).

Progression: the protective passive layer covering the steel is destroyed in this stage and if water and oxygen are present on the surface of the reinforcement, corrosion proceeds until it reaches unacceptable levels (7, 32).

\subsection{Basic corrosion process}

Concrete-embedded reinforcing steel corrosion is an electrochemical process, which means that for corrosion to take place, an anode, a cathode and an electrolyte must be present to form a corrosion cell (5). This is where the red-ox reaction takes place: the anode governs oxidation, which involves a loss of electrons [5], while during the cathodic reaction, the electrons generated in the anode combine with certain ions in the electrolyte. This electron gain constitutes reduction [6].

$$
\begin{aligned}
& \text { Reacción anódica / Anodic reaction: } \mathrm{Fe} \rightarrow \mathrm{Fe}^{2+}+2 \mathrm{e}^{-} \\
& \text {Reacción catódica / Cathodic reaction: } 2 \mathrm{e}^{-}+\mathrm{H}_{2} \mathrm{O}+\frac{1}{2} \rightarrow \mathrm{O}_{2} 2 \mathrm{OH}^{-}
\end{aligned}
$$

En el hormigón armado, la conexión metálica para el flujo de electrones del ánodo al cátodo se da en el mismo acero estructural, mientras que el hormigón toma la función de electrolito, el cual debe estar suficientemente húmedo para permitir la migración de iones, además es indispensable suficiente oxígeno para que se lleve a cabo el proceso catódico $(7,34)$.

Los iones hidroxilo presentes en la reacción catódica reaccionan con $\mathrm{Fe}^{2+}$ y producen hidróxido ferroso [7], el cual a su vez reacciona con el oxígeno y el agua presente en el hormigón produciendo hidróxido férrico [8]; el último componente corresponde al óxido de hierro hidratado [9].
In reinforced concrete, the metal required for the electrons to flow from the anode to the cathode is the structural steel itself, while the concrete, if sufficiently moist, serves as the electrolyte. Moreover, the cathodic process is also subject to the presence of a certain threshold level of oxygen $(7,34)$.

The hydroxyl ions present in the cathodic reaction interact with $\mathrm{Fe}^{2+}$ to produce ferrous hydroxide [7], which in turn reacts with the oxygen and water present in the concrete to generate ferric hydroxide [8]. The component ultimately formed is iron oxide hydrate [9].

$$
\begin{gathered}
\mathrm{Fe}^{2+}+2 \mathrm{OH}^{-} \rightarrow \mathrm{Fe}(\mathrm{OH})_{2} \\
4 \mathrm{Fe}(\mathrm{OH})_{2}+\mathrm{O}_{2}+2 \mathrm{H}_{2} \mathrm{O} \rightarrow 4 \mathrm{Fe}(\mathrm{OH})_{3} \\
2 \mathrm{Fe}(\mathrm{OH})_{3} \rightarrow \mathrm{Fe}_{2} \mathrm{O}_{3} \cdot \mathrm{H}_{2} \mathrm{O}+2 \mathrm{H}_{2} \mathrm{O}
\end{gathered}
$$

Estos productos férricos contribuyen al deterioro del hormigón. El hidróxido férrico incrementa el volumen del acero del refuerzo embebido (2 veces o más) y, por
These iron products contribute to concrete deterioration. Ferric oxide raises the volume of the embedded reinforcing steel (two-fold or more), generating tensile stress 
tanto, genera esfuerzos de tensión que producen agrietamientos en el hormigón. Cuando se produce el óxido férrico hidratado su volumen aumenta aún más, hasta 10 veces del volumen original. En esta etapa el hormigón se agrieta hasta que hay delaminación y deja expuesto el acero de refuerzo, ver Figura 2 (35). and concrete cracking as a result. The presence of ferric oxide hydrate increases the steel volume even more, up to 10 times the original size. In this stage, the concrete cracks and spalls, leaving the reinforcing steel exposed, as depicted in Figure 2 (35).

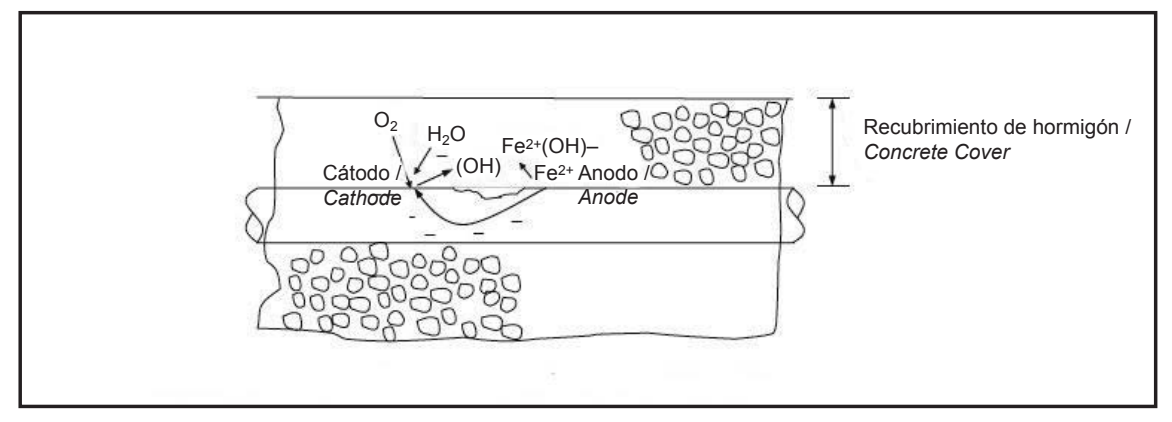

Figura 2. Proceso de corrosión del acero de refuerzo en hormigón. Tomado de El-Reedy (35) Figure 2. Corrosion in concrete-embedded reinforcing steel. From El-Reedy (35)

\subsection{Tipos de corrosión del acero}

Los tipos de corrosión pueden ser clasificados de acuerdo a diferentes criterios, tales como ambiente de exposición que induce a la corrosión, mecanismos de corrosión, daños causados, etc. Su clasificación puede ser de varios tipos: corrosión uniforme, corrosión por picado, corrosión bacteriana, corrosión galvánica, corrosión por agrietamiento y fragilización de hidrógeno, entre otros (36). A continuación se presentan dos de los tipos más importantes presentes en la corrosión del acero de refuerzo, particularmente ante la exposición a cloruros y/o carbonatación.

\subsubsection{Corrosión uniforme}

En algunos casos las zonas anódicas y catódicas se encuentran a distancias muy pequeñas y tienden a unirse en la barra de acero, de esta manera los procesos corrosivos ocurren uniformemente a través de la barra de acero de refuerzo; este tipo de corrosión, denominada corrosión uniforme, se observa usualmente en estructuras expuestas a carbonatación (36).

\subsubsection{Corrosión por picado}

En este caso la zona anódica es más pequeña que la zona catódica, pero la velocidad de penetración de la corrosión en el area anódica es muy alta, es decir, la zona anódica se corroe rápidamente; se afirma entonces que la corrosión es de tipo localizada y, debido a la formación de pequeñas "picaduras" en la superficie del acero, se le denomina corrosión por picado (36).

Este tipo de corrosión se observa principalmente en el ataque por cloruros. Los iones cloruros alcanzan áreas

\subsection{Types of steel corrosion}

Steel corrosion can be classified by a number of criteria, including type of environmental exposure, corrosion mechanisms or damage caused. One possible classification is based on corrosion type: uniform, pitting, bacterial, galvanic, cracking-induced or hydrogen embrittlement corrosion (36). The two major types of reinforcing steel corrosion, particularly when exposed to chlorides or carbonation, are described below.

\subsubsection{Uniform corrosion}

In some cases the anode and cathode zones are at a very close distance and tend to run together along the steel bar, which corrodes evenly throughout. This type of corrosion, known as uniform corrosion, is generally observed in structures exposed to carbonation (36).

\subsubsection{Pitting corrosion}

Here the anode region is smaller than the cathode region, but the corrosion penetration rate is very high in the anode area, i.e., it corrodes very quickly. This localised type of corrosion is known as pitting due to the formation of tiny "pits" on the steel surface (36).

It is observed primarily in steel subject to chloride attack. Chloride ions reach and destroy specific areas of 
particulares de la capa pasiva del acero, esta se destruye y como consecuencia hay una rápida disolución anódica en esos sitios. Durante la corrosión por picado, los iones cloruros tienden a acumularse en las "picaduras", el $\mathrm{pH}$ de la solución disminuye, por lo tanto se genera un ambiente altamente agresivo. Este es uno de los ataque más severos al acero de refuerzo, se pierde masa localizada y resistencia (36).

\section{FENÓMENOS QUE CONTRIBUYEN A LA CORROSIÓN DEL ACERO DE REFUERZO}

Como se ha mencionado anteriormente los fenómenos que contribuyen principalmente a la corrosión del acero de refuerzo son la carbonatación y el ataque por cloruros. A continuación se discuten estos dos fenómenos.

\subsection{Carbonatación}

El proceso de carbonatación se debe al ingreso de $\mathrm{CO}_{2}$ de la atmósfera al hormigón; los ambientes urbanos e industriales y en general la contaminación ambiental son la fuente necesaria para que se dé este fenómeno.

El alto pH del hormigón (del orden promedio de 13) provee una protección natural contra la corrosión del acero de refuerzo como se mencionó anteriormente, sin embargo, el proceso de carbonatación decrece el valor del pH del hormigón aproximadamente a 9 (33, 35, 3739). Para que la carbonatación tenga lugar es necesario que el dióxido de carbono entre en contacto con el agua y los componentes alcalinos presentes en los poros del hormigón; la reacción que ocurre en la solución acuosa es [10]: the passive film covering the steel, resulting in speedy anodic dissolution at these sites. In pitting corrosion, chloride ions tend to accumulate in the "pits". The solution $\mathrm{pH}$ declines, originating a highly aggressive environment. This is one of the most severe types of attack, with a localised mass and strength losses in the reinforcing steel (36).

\section{FACTORS THAT CONTRIBUTE TO REINFORCING STEEL CORROSION}

As noted earlier, the factors primarily contributing to reinforcing steel corrosion are carbonation and chloride attack, which are discussed below.

\subsection{Carbonation}

Carbonation is due to concrete penetration by atmospheric $\mathrm{CO}_{2}$, whose source is the $\mathrm{CO}_{2}$ pollution in urban and industrial environments and in general.

As explained above, while the high $\mathrm{pH}$ in concrete (13 on average) provides natural corrosion protection for the reinforcing steel, carbonation lowers concrete $\mathrm{pH}$ to approximately 9 (33, 35, 37-39). For carbonation to take place, carbon dioxide must come into contact with water and the alkaline components present in concrete pores. The reaction in the aqueous solution is as shown in [10]:

$$
\mathrm{CO}_{2}+\mathrm{Ca}(\mathrm{OH})_{2} \stackrel{\mathrm{H}_{2} \mathrm{O}, \mathrm{NaOH}}{\longrightarrow} \mathrm{CaCO}_{3}+\mathrm{H}_{2} \mathrm{O}
$$

Cabe anotar, que además de la portlandita y el C S H, otras fases hidratadas, aluminatos y sulfoaluminatos, también sufren transformaciones frente a la incorporación del $\mathrm{CO}_{2}$. Es el caso de la fase AFt, la cual puede originar además del $\mathrm{CaCO}_{3}$, yeso y gel de alúmina.

El mecanismo de transporte o movimiento de la carbonatación dentro del hormigón es explicado por la teoría de la difusión, y se describe por la primera ley de Fick, según [11] $(35,39-41)$ :
In addition to portlandite and $\mathrm{CS} \mathrm{H}$, other aluminate and sulfoaluminate hydrates are also transformed in the presence of $\mathrm{CO}_{2}$. This is the case of AFt, which may originate $\mathrm{CaCO}_{3}$, gypsum and alumina gel.

Diffusion as per Fick's first law (see [11]) is the mechanism governing carbonate transport across concrete (35, 39-41):

$$
\mathrm{x}=\mathrm{K}_{\mathrm{CO}_{2}} \sqrt{\mathrm{t}}
$$

Donde $\mathrm{x}$ corresponde a la profundidad de carbonatación después de un tiempo $t$ en $\mathrm{mm}$; $\mathrm{t}$ corresponde al tiempo en años y $\mathrm{K}$ es la constante de carbonatación en $\mathrm{mm} /$ año1/2.
Where $x$ is the depth of carbonation in mm after time $t$ in years and $K$ is the carbonation constant in $\mathrm{mm} /$ year $^{1 / 2}$. 
La velocidad de carbonatación depende de factores ambientales y factores relacionados al hormigón mismo. Entre los factores ambientales más importantes se encuentra la humedad relativa; el proceso de difusión del $\mathrm{CO}_{2}$ no se producirá en hormigones que están totalmente saturados de agua y el $\mathrm{CO}_{2}$ en hormigones totalmente secos no reacciona, es por ello que la humedad relativa ideal para propiciar el fenómeno está entre el 50 y el $70 \%(35,38,42)$. La concentración de $\mathrm{CO}_{2}$ en la atmósfera puede variar desde $0,03 \%$ para ambientes rurales y más del $0,1 \%$ para ambientes urbanos, estos últimos tienen una mayor incidencia para que se presente la carbonatación y, por último, un incremento de temperatura podría acelerar notablemente la velocidad de carbonatación (7).

Los factores relacionados al hormigón que afectan la capacidad de resistir la propagación del $\mathrm{CO}_{2}$ son: un inadecuado proceso de curado y una mala compactación, es decir, hormigones más permeables sufren una carbonatación más rápida (42). Dado esta situación, a relaciones agua/cemento bajas se reduce la movilidad del $\mathrm{CO}_{2}$ en el hormigón, limitando la carbonatación a la superficie $(11,35,38,39,43)$.

Con respecto a los cementos adicionados con cenizas volantes, puzolanas naturales y escorias siderúrgicas en grandes porcentajes, son más susceptibles a la carbonatación que los no-adicionados, por ello es recomendable un buen curado para que las reacciones puzolánicas alcancen su desarrollo $(3,44)$, a partir de lo cual su desempeño podría ser positivo.

De acuerdo con la Norma Europea EN 206 (9) se definen cuatro clases de severidad a la corrosión inducida por carbonatación, identificadas como XC1 hasta XC4, tal como se puede apreciar en la Tabla 6. Las características recomendadas para el hormigón se incluyen en la Tabla 7.

Para determinar la profundidad de carbonatación, generalmente se hace uso de la Norma Española UNE 112011 (45), que consiste en medir la profundidad de la zona de
The carbonation rate depends on environmental factors and factors relating to the concrete itself. One of the most important environmental factors is relative humidity; $\mathrm{CO}_{2}$ neither spreads across water-saturated concretes nor reacts in completely dry concretes: the relative humidity that favours diffusion ranges from 50 to $75 \%$ $(35,38,42) . \mathrm{CO}_{2}$ concentration in the atmosphere may fluctuate from $0.03 \%$ in rural environments to over $0.1 \%$ in cities, where the incidence of carbonation is higher. Lastly, temperature can accelerate the carbonation rate substantially (7).

The concrete-related factors that affect resistance to $\mathrm{CO}_{2}$ propagation are unsatisfactory curing and poor consolidation. In other words, the more permeable a concrete, the faster carbonation spreads (42). Hence, lower water/ cement ratios reduce $\mathrm{CO}_{2}$ mobility in concrete, limiting carbonation to the surface layers (11, 35, 38, 39, 43).

Since blended cements containing high proportions of fly ash, natural pozzolans or blast furnace slag are more susceptible to carbonation than unblended cements, good curing is recommended in the former to ensure that the pozzolanic reactions run through to completion $(3,44)$ and thereby guarantee good concrete performance.

The four carbonation exposure classes, XC1 to XC4, defined in European standard EN 206 (9) are listed in Table 6. The recommended characteristics for concrete are given in Table 7.

Carbonation depth is generally determined as set out in Spanish standard UNE 112011 (45). In this method the depth of the carbonation zone (low pH) is measured with

Tabla 6 / Table 6

Clase de exposición para corrosión inducida por carbonatación de acuerdo a la norma EN206(9). EN206 (9) carbonation exposure classes.

\begin{tabular}{|c|c|c|}
\hline Clase / Class & Descripción / Description & Ejemplos / Example \\
\hline XC1 & $\begin{array}{c}\text { Seco o permanentemente húmedo / } \\
\text { Dry or permanently moist }\end{array}$ & $\begin{array}{c}\text { Hormigón en el interior de edificios con una humedad relativa del aire baja; } \\
\text { Hormigón permanentemente sumergido en agua / Concrete in building interiors with } \\
\text { a low relative humidity; concrete permanently submerged in water }\end{array}$ \\
\hline XC2 & Húmedo, rara vez seco / Moist, rarely dry & $\begin{array}{c}\text { Superficies de hormigón en contacto con agua durante mucho tiempo; Un gran } \\
\text { número de cimentaciones / Concrete surfaces in contact with water over long } \\
\text { periods; many foundations }\end{array}$ \\
\hline XC3 & Humedad moderada / Moderate moisture & $\begin{array}{c}\text { Hormigón en el interior de edificios con una humedad relativa del aire media o alta } \\
\text { / Concrete in building interiors with medium or high relative humidity }\end{array}$ \\
\hline XC4 & Ciclos de humedad y sequedad / & $\begin{array}{c}\text { Superficies sometidas al contacto con el agua, sin que puedan considerarse de } \\
\text { la clase XC2 / Surfaces exposed to water, but not in the conditions described for } \\
\text { class XC2 }\end{array}$ \\
\hline
\end{tabular}


Tabla 7 / Table 7

Valores límites recomendados para el hormigón según EN206 (9) - Carbonatación. EN206 (9) specifications for concrete exposed to carbonation.

\begin{tabular}{|c|c|c|c|}
\hline Clase / Class & $\begin{array}{c}\text { Máxima relación a/c / } \\
\text { Maximum w/c ratio }\end{array}$ & $\begin{array}{c}\text { Clase de resistencia mínima / } \\
\text { Minimum strength class }\end{array}$ & $\begin{array}{c}\text { Contenido mínimo de cemento }\left(\mathrm{kg} / \mathbf{m}^{3}\right) \text { / } \\
\text { Minimum cement content }\end{array}$ \\
\hline $\mathrm{XC} 1$ & 0.65 & $\mathrm{C} 20 / 25$ & 260 \\
\hline $\mathrm{XC2}$ & 0.60 & $\mathrm{C} 25 / 30$ & 280 \\
\hline $\mathrm{XC} 3$ & 0.55 & $\mathrm{C} 30 / 37$ & 280 \\
\hline $\mathrm{XC} 4$ & 0.50 & $\mathrm{C} 30 / 37$ & 300 \\
\hline
\end{tabular}

carbonatación ( $\mathrm{pH}$ inferior) mediante el uso de un indicador de $\mathrm{pH}$ (solución de fenolftaleína al $1 \%$ en alcohol etílico). Las áreas donde el pH es mayor a 9 se tornan color violeta, mientras las áreas carbonatadas serán aquellas donde no se aprecia color. Esta prueba revela el denominado frente de carbonatación $(3,35,43)$. Además de este método se pueden utilizar técnicas complementarias tales como análisis térmico diferencial (TG/DTG/DTA), difracción de rayos $X(D R X)$ y espectroscopia de infrarrojo (FTIR).

\subsection{Ataque por cloruros}

El ataque por cloruros al hormigón puede provenir de dos fuentes principales, en la primera los iones cloruros pueden estar presentes dentro de la mezcla del hormigón (p.e., áridos contaminados, agua de mar o contaminada, cemento y/o aditivos con contenidos altos de cloruros); en la segunda los cloruros ingresan desde el exterior. Esta última se puede dar por el uso de sales de deshielo, exposición a ambientes marinos, presencia de cloruros en sustancias químicas que puedan atacar al hormigón, entre otros $(3,7,35)$.

La penetración del ion cloruro $\left(\mathrm{Cl}^{-}\right)$desde el exterior produce un perfil en el hormigón, caracterizado por altos contenidos de cloruros cerca a la superficie externa y una disminución de su contenido hacia el interior. Este perfil puede aproximarse por la segunda ley de Fick [12]: a $\mathrm{pH}$ indicator (phenolphthalein in $1 \%$ ethyl alcohol). The areas where the $\mathrm{pH}$ is greater than 9 turn violet, whereas the carbonated areas are colourless. This trial defines the so-called carbonation front $(3,35,43)$. Supplementary techniques may also be used, including differential thermal analysis (TG/DTG/DTA), X-ray diffraction (XRD) and infrared spectroscopy (FTIR).

\subsection{Chloride attack}

The chloride ions that attack concrete may be internal, i.e., present in the concrete mix (e.g., contaminated aggregate, polluted or sea water, cement or admixtures with high chloride contents), or external: de-icing salts, marine environments or the presence of chlorides in chemical substances that may attack the concrete (3, 7, 35).

Chloride ion ( $\mathrm{Cl}$ ) penetration from the outside is characterised by a pattern of high concentrations near the outer surface and a gradual inward decline. This pattern can be approximated with Fick's second law [12]:

$$
C_{x, t}=C_{s}\left[1-\operatorname{erf}\left(\frac{x}{2 \sqrt{D_{a} t}}\right)\right]
$$

Donde, $\mathrm{C}_{\mathrm{x}, \mathrm{t}}$ corresponde a la concentración de cloruros a una profundidad $\mathrm{x}$ con un tiempo $\mathrm{t}$; $\mathrm{C}_{\mathrm{s}}$ la concentración de cloruros en la superficie en $\mathrm{kg} / \mathrm{m}^{3}$; erf la función de error; $D_{a}$ el coeficiente de difusión aparente en $\mathrm{cm}^{2} / a n ̃ o$ y t el tiempo de exposición $(40,46,47)$. En recientes investigaciones, Princigallo (48) presenta un método para medir el coeficiente de difusividad de cloruros partiendo de una aplicación analítica de la segunda ley de Fick en un sistema de coordenadas cilíndrico, afirma el autor que este método disminuye el tiempo de ensayo ya que es posible obtener resultados satisfactorios en tan solo un mes. where $C_{\mathrm{x}, \mathrm{t}}$ is the chloride concentration at depth $\mathrm{x}$ in time $t ; C_{\mathrm{s}}$ is the chloride concentration on the surface in $\mathrm{kg} /$ $\mathrm{m}^{3}$; erf is the error function; $D_{\mathrm{a}}$ is the apparent diffusion coefficient in $\mathrm{cm}^{2} /$ year and $t$ is the exposure time (40, $46,47)$. In recent research, Princigallo (48) described a method for measuring the chloride diffusion coefficient based on an analytical application of Fick's second law in a system of cylindrical coordinates. The author claimed that this method reduces test time and that satisfactory results can be obtained in just one month. 
Los iones cloruros una vez penetran el hormigón se distribuyen como cloruros enlazados y cloruros libres. Los primeros corresponden a aquellos que se enlazan químicamente al reaccionar con el aluminato tricálcico $\left(C_{3} A\right)$ presente en la pasta para así formar cloroaluminatos cálcicos, compuesto conocido como "Sal de Friedel", que a diferencia de la etringita, no resulta ser expansiva $(3,40)$. En este sentido es recomendable la utilización de cementos con alto contenido de $\mathrm{C}_{3} \mathrm{~A}$ para hormigones expuestos a cloruros. Por el contrario, los cloruros libres se difunden hasta alcanzar el acero de refuerzo, donde se acumulan hasta lograr una concentración critica, la cual tiene la capacidad de destruir la capa pasiva del acero e iniciar el proceso corrosivo (32). Cabe anotar que entre los factores que más influencian el contenido crítico de cloruros están la calidad de la interface hormigón/acero y el potencial electroquímico del acero de refuerzo, el cual está relacionado con la cantidad de oxígeno que puede alcanzar la superficie del acero (49). Díaz-Benito et al. (50) presentan la técnica de microscopía de fuerza atómica (AFM) como una excelente alternativa para observar el comportamiento del acero frente a la corrosión; los investigadores realizan el estudio en medios que simulan los contenidos de los poros del hormigón y mediante el análisis de las imágenes y la evolución de la rugosidad de la superficie del acero con el tiempo de exposición confirman la tendencia del acero a pasivarse en sus inicios y posteriormente la destrucción de la capa pasiva debido al ataque por cloruros.

La movilidad de los iones cloruro dentro del hormigón está relacionada con su permeabilidad, por ello algunos factores importantes a tener en cuenta son: la relación agua/cemento, el tipo y proporción de cemento a utilizar y el proceso de curado $(46,48,51)$. La presencia de adiciones (puzolánicas y siderúrgicas) modifican la porosidad y reducen la permeabilidad, mejorando igualmente la resistencia a la penetración de los cloruros en el hormigón (49).

De acuerdo con la Norma Europea EN 206 (9) se definen tres clases de severidad a la corrosión inducida por cloruros de origen distinto al marino (XD1, XD2, XD3), al igual que para la corrosión inducida por cloruros procedentes del agua de mar (XS1, XS2, XS3), tal como se indica en las Tablas 8 y 9, respectivamente. La Tabla 10 presenta las características recomendadas para la composición del hormigón.

El máximo contenido de cloruros de acuerdo con la norma EN 206 (9) va de 0,2 a 0,4\% de iones cloruros en relación a la masa de cemento para estructuras con acero reforzado y 0,1 al 0,2\% para estructuras de hormigón pretensado. La norma ASTM C1202 (52) permite evaluar la susceptibilidad del hormigón a los iones cloruros mediante un ensayo rápido de permeabilidad;
After penetrating the concrete, the chloride ions may bind or remain free. In the former case, they react with the tricalcium aluminate $\left(C_{3} A\right)$ present in the paste to form calcium chloraluminates, a compound known as Friedel's salt which, unlike ettringite, is not expansive $(3,40)$. The use of cements with a high $C_{3} A$ content is consequently recommended for concretes exposed to chlorides. The free chlorides, in turn, diffuse to the depth of the reinforcing steel, where they accumulate until the concentration reaches a critical level able to destroy the passive cover on the steel and initiate corrosion (32). The factors with the greatest impact on the critical chloride content include the quality of the concrete/steel interface and the electrochemical potential of the reinforcing steel. The latter, in turn, is related to the amount of oxygen that can reach its surface (49). DíazBenito et al. (50) used atomic force microscopy (AFM) to observe steel corrosion behaviour; these researchers studied media simulating concrete pore content and, by analysing the images and the variation in steel surface roughness during exposure, confirmed that the initially passivated steel subsequently lost its passive layer to chloride attack.

Since chloride ion mobility is related to concrete permeability, the factors to be borne in mind are the water/ cement ratio, the type and proportion of cement to be used and the curing process $(46,48,51)$. The presence of (pozzolanic and iron-based) additions modify porosity and lower permeability, enhancing concrete resistance to chloride penetration (49).

European standard EN 206 (9) defines three exposure classes for corrosion induced by chlorides other than from seawater (XD1,XD2,XD3), and three for corrosion induced by chlorides from seawater (XS1, XS2, XS3), as specified in Tables 8 and 9, respectively. The recommended characteristics for concrete composition are given in Table 10.

The maximum chloride content allowed by standard EN 206 (9) ranges from 0.2 to $0.4 \%$ of the cement mass for reinforced concrete and from 0.1 to $0.2 \%$ for prestressed concrete structures. ASTM standard C1202 (52) describes a quick permeability test for assessing concrete susceptibility to chloride ions. Although this technique has given rise to some controversy and others have 
Tabla 8 / Table 8

Clase de exposición para corrosión inducida por cloruros (no marino) de acuerdo a la norma EN206 (9). EN206 (9) chloride ion (other than seawater) exposure classes.

\begin{tabular}{|c|c|c|}
\hline Clase / Class & Descripción / Description & Ejemplos / Example \\
\hline XD1 & $\begin{array}{c}\text { Moderadamente húmedo / } \\
\text { Moderately moist }\end{array}$ & $\begin{array}{c}\text { Superficies de hormigón expuestas a cloruros transportados por vía aérea / } \\
\text { Concrete surfaces exposed to air-borne chlorides }\end{array}$ \\
\hline XD2 & $\begin{array}{c}\text { Húmedo, rara vez seco / } \\
\text { Moist, rarely dry }\end{array}$ & $\begin{array}{c}\text { Piscinas y hormigones en contacto con aguas industriales que contengan cloruros / } \\
\text { Swimming pools and concretes in contact with chloride-containing industrial water }\end{array}$ \\
\hline XD3 & Ciclos de humedad y sequedad / \\
Wet-dry cycles & $\begin{array}{c}\text { Elementos de puentes expuestos a salpicaduras que contengan cloruros; pavimentos; } \\
\text { Losas de aparcamientos / Bridge members exposed to spray-borne chlorides; } \\
\text { pavements; car park slabs }\end{array}$ \\
\hline
\end{tabular}

Tabla 9 / Table 9

Clase de exposición para corrosión inducida por cloruros procedentes del agua de mar - EN206 (9). EN206 (9) (seawater) chloride ion exposure classes.

\begin{tabular}{|c|c|c|}
\hline Clase / Class & Descripción / Description & Ejemplos / Example \\
\hline XS1 & $\begin{array}{c}\text { Exposición al aire que transporta sales marinas, pero sin contacto directo } \\
\text { con el agua de mar / } \\
\text { Exposure to air-borne sea salts, but no direct contact with seawater }\end{array}$ & $\begin{array}{c}\text { Estructuras en la costa o en sus proximidades / } \\
\text { Structures on or near the shore }\end{array}$ \\
\hline XS2 & Sumergido permanentemente / Permanently underwater & $\begin{array}{c}\text { Elementos de estructuras marinas / } \\
\text { Marine structure members }\end{array}$ \\
\hline XS3 & Zonas sometidas a la marea, ala salpicadura y a la espuma de mar / & Elementos de estructuras marinas / \\
Areas exposed to sea spray & Marine structure members \\
\hline
\end{tabular}

Tabla 10 / Table 10

Valores límites recomendados para hormigón según EN206 (clases XD1 a XD3 y XS1 a XS3).

EN206 (9) specifications for concrete exposed to chloride ions (classes XD1-XD3 and XS1 to XS3).

\begin{tabular}{|c|c|c|c|}
\hline Clase / Class & $\begin{array}{c}\text { Máxima relación a/c / } \\
\text { Maximum w/c ratio }\end{array}$ & $\begin{array}{c}\text { Clase de resistencia mínima / } \\
\text { Minimum strength class }\end{array}$ & $\begin{array}{c}\text { Contenido mínimo de cemento (kg/m }{ }^{3} \text { / } \\
\text { Minimum cement content }\end{array}$ \\
\hline \multicolumn{4}{|c|}{ Otros cloruros distintos del agua de mar / Chloride ions from other than seawater } \\
\hline XD1 & 0.55 & C30/37 & 300 \\
\hline XD2 & 0.55 & C30/37 & 300 \\
\hline XD3 & 0.45 & C35/45 & 320 \\
\hline XS1 & 0.50 & Cgua de mar / Chloride ions from seawater \\
\hline XS2 & 0.45 & C30/37 & 300 \\
\hline XS3 & 0.45 & C35/45 & 320 \\
\hline
\end{tabular}

aunque esta técnica ha sido muy controvertida y se han desarrollado otros métodos continúa siendo el utilizado con fines comparativos por numerosos investigadores, particularmente por la rapidez del ensayo y su reducida complejidad.

\section{MÉTODOS DE PREVENCIÓN Y CONTROL}

La prevención de la corrosión del acero y otros tipos de fenómenos de deterioro empieza desde la fase de diseño, cálculos estructurales, selección de materiales y sus proporciones, preparación, compactación y curado. Dependiendo del ambiente de exposición se dan los valores mínimos recomendados para producir un hormigón de calidad, tal como se recomienda en los códigos been subsequently developed, it continues to be used for comparative purposes by many researchers, primarily because the test can be swiftly and easily run.

\section{PREVENTION AND CONTROL METHODS}

Preventing steel corrosion and other types of deterioration begins in the design and structural engineering stage, and continues with the choice of materials, batching, preparation, consolidation and curing. Building codes list the minimum recommended values required to produce quality concrete in each type of exposure. One factor that must be borne in mind is 
constructivos. Otro factor importante para tener en cuenta es el espesor de recubrimiento de hormigón; al respecto la Norma Europea EN 206 (9) recomienda los valores incluidos en la Tabla 11. Sin embargo, a pesar de estas consideraciones en ocasiones son necesarios otros métodos suplementarios para extender la vida útil de las estructuras. Una buena protección es extender el tiempo en el cual los cloruros o el frente de carbonatación alcanzan el acero de refuerzo. A continuación se presentan algunos métodos de prevención y control para la corrosión del acero de refuerzo. concrete cover thickness: the values recommended in European standard EN 206 (9) are given in Table 11. On occasion, however, supplementary methods need to be deployed to extend a structure's service life. Good protection lengthens the time it takes chloride ions or the carbonation front to reach the reinforcing steel. A number of steel corrosion prevention and control methods are discussed below.

Tabla 11 / Table 11

Valores mínimos para el recubrimiento de hormigón según EN206 (9). EN206 (9) concrete cover requirements.

\begin{tabular}{|c|c|c|}
\hline Acción / Action & $\begin{array}{c}\text { Clase de exposición / } \\
\text { Exposure class }\end{array}$ & $\begin{array}{c}\text { Mínimo recubrimiento de hormigón (mm) para hormigón reforzado* } \\
\text { Minimum reinforcement cover }(\mathbf{m m})^{*}\end{array}$ \\
\hline Sin riesgo / No risk & $\mathrm{X} 0$ & 10 \\
\hline \multirow{2}{*}{$\begin{array}{c}\text { Corrosión inducida por carbonatación / } \\
\text { Carbonation-induced corrosion }\end{array}$} & $\mathrm{XC1}$ & 15 \\
\cline { 2 - 3 } & $\mathrm{XC2}, \mathrm{XC} 3$ & 25 \\
\hline \multirow{2}{*}{$\begin{array}{c}\text { Corrosión inducida por cloruros / } \\
\text { Chloride-induced corrosion }\end{array}$} & $\mathrm{XS} 4, \mathrm{XD} 1$ & 30 \\
\cline { 2 - 3 } & $\mathrm{XS} 2, \mathrm{XD2}$ & 40 \\
\cline { 2 - 3 } & $\mathrm{XS} 3, \mathrm{XD} 3$ & 45 \\
\hline
\end{tabular}

* A estos valores se debe incrementar $10 \mathrm{~mm}$ para obtener la profundidad nominal del recubrimiento / The nominal cover depth is 10 mm greater than these values.

\subsection{Inhibidores de corrosión}

Los inhibidores de corrosión son una buena alternativa de protección debido a su bajo costo y fácil aplicación (53). Se definen como una sustancia química que disminuye la velocidad de corrosión cuando se encuentra presente en un sistema corrosivo a una concentración adecuada, sin cambiar significativamente la concentración de cualquier otro agente corrosivo (54).

De acuerdo a los mecanismos de protección los inhibidores se clasifican en anódicos, catódicos, o mezclados $(35,53,54)$.

Inhibidores anódicos: actúan en la disolución del acero y estos reducen la velocidad de corrosión por un aumento en el potencial de corrosión del acero (nitrito de calcio, nitrito de sodio, benzoato de sodio, cromato de sodio, entre otros).

Inhibidores catódicos: actúan en la reacción del oxígeno con la superficie del acero y reducen la velocidad de corrosión por una disminución en el potencial de corrosión (hidróxido de sodio y carbonato de sodio).

Inhibidores mixtos: actúan como anódicos y catódicos, reducen la velocidad de corrosión sin presentar un cambio significativo en el potencial de corrosión (materiales del grupo de los hidrófobos, aminas y aminoalcoholes) (54).

\subsection{Corrosion inhibitors}

Corrosion inhibitors are low in cost and readily applied, making them a good protective option (53). They are defined as chemical substances that, in appropriate concentrations, reduce the corrosion rate in a corrosive system while inducing no significant change in the concentration of any corrosive agent (54).

Depending on the protection mechanism involved, inhibitors are classified as anodic, cathodic or mixed (35, 53, 54).

Anodic inhibitors (e.g., calcium nitrite, sodium nitrite, sodium benzoate, and sodium chromate) affect steel dissolution and lower the corrosion rate by raising the steel corrosion potential.

Cathodic inhibitors (such as sodium hydroxide and sodium carbonate) affect the reaction between oxygen and the steel surface, lowering the corrosion rate by decreasing the corrosion potential.

Mixed inhibitors (hydrophobic materials, amines and alkamines) act as anodic or cathodic substances, lowering the corrosion rate without significantly changing the corrosion potential (54). 
Los inhibidores de corrosión, en general, han sido utilizados principalmente para el ataque por cloruros (7). La Unión Soviética fue el pionero en utilizar inhibidores de nitrito de calcio como estrategia de protección contra la corrosión causada por las sales de deshielo; en Estados Unidos y Japón ha sido utilizado por años (54). Sin embargo, su uso para la corrosión debido a la carbonatación es aún controvertido (7).

\subsection{Recubrimientos}

Entre los métodos de protección se encuentran los recubrimientos que son aplicados sobre el acero o sobre la superficie del hormigón según sea el caso, estos sistemas se consideran una opción económicamente rentable y viable. Hay tres tipos de materiales, recubrimientos metálicos, inorgánicos y orgánicos (poliméricos), estos se pueden encontrar en forma líquida o en polvo (55).

Los recubrimientos más utilizados son los orgánicos por su simplicidad en la aplicación, flexibilidad, resistencia química, adhesión, dureza y durabilidad. Estos funcionan como barrera para el aislamiento del acero de la humedad, cloruros y oxígeno (epóxicos, vinílicos, asfalto, entre otros). Se han evaluado recubrimientos de poliuretano, acrílicos de látex, de redes poliméricas epoxi-fenólicas interpenetrantes y se reporta un buen desempeño de los mismos frente a la corrosión del acero (55). El principal problema de las barras de acero que tienen recubrimientos epóxicos es la resistencia de adherencia entre el acero recubierto y el hormigón (56).

Por otra parte, los recubrimientos metálicos para el acero de refuerzo pueden ser nobles o de sacrificio. Estos últimos son elaborados de materiales metálicos que tienen un potencial de corrosión más negativo que el acero (p.e. zinc). Si el recubrimiento se rompe, la celda galvánica se activa y este se corroe mientras se protege al acero de refuerzo. Los recubrimientos nobles tales como cobre y níquel no necesitan ser corroídos, sin embargo, si se rompen el acero se corroerá (57). Con respecto a las desventajas los recubrimientos o baños de zinc pueden incrementar el agrietamiento, ya que los aceros galvánicos son más susceptibles a la fragilización de hidrógeno.

Por último, los recubrimientos (orgánicos e inorgánicos) utilizados sobre la superficie del hormigón ofrecen una solución efectiva y viable para proteger el acero embebido en el hormigón. Los diferentes tipos de recubrimientos que se encuentran dentro de esta categoría son pinturas inorgánicas, dispersiones acrílicas, resinas epóxicas, entre otros (58). Moon et al. (59) presentan en su investigación un recubrimiento inorgánico basado en un compuesto de silicato de calcio, el cual por poseer propiedades similares al cemento tiene una buena
Corrosion inhibitors have been used primarily to prevent chloride attack (7). The Soviet Union pioneered the use of calcium nitrite inhibitors as a strategy for protecting steel against de-icing salt-induced corrosion, although the method has been in use for years in the United States and Japan (54). Its use to detain carbonation corrosion remains controversial, however (7).

\subsection{Coatings}

Coatings constitute another protective method. Applied to the reinforcing steel or the concrete surface, depending on the case, these systems are regarded as a cost-effective and technically viable option. Three types of liquid or powdery materials may be used: metallic, inorganic or organic (polymers) (55).

Organic coatings (epoxies, vinyls, asphalt) are the type most commonly applied because of their simplicity of use, flexibility, chemical resistance, bonding, hardness and durability. They act as a barrier, insulating the steel from moisture, chlorides and oxygen. Polyurethane, latex acrylic and interpenetrating epoxy-phenol polymeric grid coatings have been reported to deliver good anti-corrosion performance for steel (55). The main problem posed by epoxy-coated steel is the weak coated bar - concrete bond (56).

Metal coatings for reinforcing steel, in turn, may be sacrificial or otherwise. The former are made with metallic materials with a more negative corrosion potential than steel (zinc, for instance). If the coating is ruptured, the galvanic cell is activated and corrodes, thereby protecting the reinforcing steel. Coatings such as copper and nickel need not corrode, although if they are ruptured steel corrosion sets in (57). The drawback to zinc coatings is that they may favour cracking, for galvanised steel is more susceptible to hydrogen embrittlement.

Lastly, the (organic and inorganic) coatings used on the concrete surface provide an effective and viable solution for protecting steel embedded in concrete. The coatings in this category include inorganic paint, acrylic dispersions and epoxy resins (58). Moon et al. (59) studied an inorganic coating based on a calcium silicate compound that bonded well to concrete because of its similarity to cement, claiming that this coating both lowered chloride penetration in a concrete and retarded carbonation. Sealers and membranes have also been used to reduce 
adherencia al hormigón, afirma que este recubrimiento expuesto a cloruros presenta una baja penetración de los mismos con respecto a un hormigón sin recubrimiento, asimismo retarda el proceso de carbonatación. En el mismo sentido se han usado selladores y membranas para reducir la penetración de cloruros y la carbonatación $(35,57)$, en el último caso el principal inconveniente es el deterioro y fragilización en el tiempo de servicio. En estudios más recientes se ha propuesto la aplicación de geopolímeros como recubrimiento inorgánico, estos materiales poseen una baja permeabilidad y propiedades anticorrosivas, y pueden ser utilizados como protección de estructuras de hormigón en ambiente marino (60).

\subsection{Adición de materiales minerales}

Las adiciones minerales, generalmente puzolanas, son materiales que contienen sílice amorfa y componentes de alúmina. La reacción de estos materiales con la porlandita (hidróxido de calcio) y agua generan el gel C-S-H acorde a [13]. Asimismo contribuyen a reducir la permeabilidad y en consecuencia la durabilidad del hormigón endurecido se incrementa. chloride penetration and carbonation $(35,57)$. The main drawback to using the latter is its deterioration and embrittlement during concrete service life. More recent studies have proposed the application of geopolymers as an inorganic coating. These materials exhibit low permeability and anti-corrosive properties and may be used as protection for concrete structures in marine environments (60).

\subsection{Mineral additions}

Mineral, generally pozzolanic, additions, are materials containing amorphous silica and alumina components. The reaction between these materials and portlandite (calcium hydroxide) and water generates $\mathrm{C}-\mathrm{S}-\mathrm{H}$ gel as in [13]. Such additions also contribute to lowering permeability and consequently enhance hardened concrete durability.

$$
\text { puzolana + agua }+\mathrm{Ca}(\mathrm{OH})_{2} \rightarrow \mathrm{C}-\mathrm{S}-\mathrm{H}
$$

Entre este tipo de adiciones se encuentran las siguientes:

Humo de sílice (SF): este consiste al menos de un $85 \%$ de sílice amorfa; está disponible en polvo, polvo densificado o mezcla líquida. El SF es una puzolana altamente efectiva por su alto contenido de sílice, su tamaño de partícula fino $(0,1$ hasta $0,5 \mu \mathrm{m})$ y su gran superficie específica (2). Sus pequeñas partículas actúan como taponamiento de los poros existentes dando como resultado un hormigón menos permeable (61); a su vez acelera los procesos de hidratación del cemento, siendo su acción puzolánica bastante activa en las primeras horas de hidratación (62). Porcentajes de SF por encima del 10\% afectan la reología de la mezcla e incrementan los costos, por lo cual se sugiere el uso de porcentajes entre 6 y $8 \%$ de la masa de cemento (57). Shekarchi et al. (63) afirman que el reemplazo del contenido de cemento por SF provee un hormigón con una baja permeabilidad a cloruros, sin embargo, el incremento del contenido de SF no resultó ser proporcional a la reducción del coeficiente de difusión de cloruros. Asimismo, se reporta que se reduce la capacidad de enlazar cloruros en la pasta de cemento endurecida debido a su bajo contenido de alúmina (64). Con respecto a la carbonatación, Kulakowski et al. (65) afirman que los hormigones con SF y relaciones agua/cemento de 0,45 a 0,50 incrementan la resistencia a la carbonatación, sin embargo, puede llegar a tener un efecto perjudicial si las relaciones agua/cemento

\section{A brief description of some of these additions is provided} below.

Silica fume (SF) contains at least $85 \%$ amorphous silica; it is marketed as a powder, a densified powder or a suspension. SF is a highly effective pozzolan thanks to its high silica content, fine particle size $(0.1$ to $0.5 \mu \mathrm{m})$ and large specific surface (2). Its small particles plug the existing pores, rendering concrete less permeable (61) and accelerating cement hydration, for its pozzolanic action is quite intense during the first few hours of hydration (62). Since SF percentages of over $10 \%$ affect mix rheology and raise costs, the recommended dose is 6 to $8 \%$ of the cement mass (57). Shekarchi et al. (63) claimed that replacing cement with SF resulted in low chloride permeability, although the SF content was not proportional to the reduction in the chloride diffusion coefficient. They also reported that hardened cement paste bondability to chlorides declined due to its low alumina content (64). Kulakowski et al. (65), in turn, contended that SFcontaining concretes with water/cement ratios of 0.45 to 0.50 raise carbonation resistance, while noting that the use of higher ratios may be detrimental. They observed the ideal concentration to range from 5 to $10 \%$. 
son superiores, afirmando así que el rango ideal de concentración es del 5 al 10\%; otros investigadores han reportado resultados controvertidos en cuanto al frente de carbonatación (62). El uso del SF en sistemas cementicios está especificado en la norma ASTM C1240 (66).

Escoria granulada de alto horno (GBFS): es un subproducto de la industria del acero y el hierro, está compuesto de sílice, cal, y alúmina, con pequeñas cantidades de magnesio, óxidos alcalinos y óxidos de hierro. La composición de la escoria depende del proceso industrial y las materias primas utilizadas $(2,57)$. La finura y la superficie específica de la GBFS es similar a la del cemento (2). Con altos porcentajes de reemplazo de GGBS se observa una baja resistencia a la carbonatación (67, $68)$, se recomienda utilizar un porcentaje límite del $50 \%$ (68). Cabe mencionar, que si el contenido de escoria, con respecto a la masa de cemento, es del $50 \%$ o más se debe tener un adecuado proceso de curado ya que pueden presentarse efectos adversos en la permeabilidad (2). Song y Saraswathy (68) afirman que el $40 \%$ de reemplazo no tiene un efecto significante en las velocidades de corrosión, solo a partir del $60 \%$ se ve el efecto. Al respecto, Topçu y Boga (69) reportan en especímenes con $25 \%$ de reemplazo de cemento por GBFS a 90 días de curado, además de altas resistencias a la compresión, una alta resistencia a la corrosión del acero. En general, los autores coinciden en que esta adición reduce la porosidad del hormigón y se da un refinamiento de poros, ofreciendo una resistencia importante a la entrada del ion cloruro (70). Con altos niveles de reemplazo (45-65\%) de escoria y una relación a/c de 0,40 se ha confirmado la resistencia a la penetración del ion cloruro para bloques expuestos a zonas de mareas por 25 años (71). Este efecto, en la penetración de los cloruros se atribuye a la capacidad de enlazar cloruros (formación de Sal de Friedel) reduciendo así su coeficiente de difusión $(70,72,73)$. Adicionalmente, se ha comprobado que la adición de GBFS, aunque disminuye el pH de la solución de poros, no tiene efectos adversos para la corrosión del acero $(68,74)$. El uso de GBFS en sistemas cementicios está especificado en la norma ASTM C989 (75).

Ceniza Volante (FA): es un subproducto proveniente de la quema del carbón generado por calderas, plantas o estaciones de energía, etc. La FA de buena calidad generalmente es de carácter amorfo y presenta forma esférica con tamaños que varían entre 10 y $100 \mu \mathrm{m}$. Por su morfología incrementa la trabajabilidad del hormigón sin incrementar la cantidad de agua necesaria en la mezcla (2). La adición de FA tiene efectos benéficos en algunas propiedades mecánicas del hormigón, además tiene buen desempeño frente al ataque por iones cloruros, porque se disminuye la permeabilidad del hormigón (76-78); igual que en el caso de las escorias, su efecto se atribuye a la capacidad de enlazar cloruros principalmente por su alto
Other authors have reported contradictory results in connection with the carbonation front (62). ASTM standard C1240 (66) lays down recommendations on the use of SF in cementitious systems.

Granulated blast furnace slag (GBFS) is a by-product of the iron and steel industry consisting of silica, lime and alumina with traces of magnesium and alkaline and iron oxides. Slag composition depends on the industrial process and raw materials used $(2,57)$. GBFS fineness and specific surface are similar to these properties in cement (2). Since at high GBFS replacement rates, carbonation resistance is low $(67,68)$, the maximum recommended rate is $50 \%$ (68). Moreover, where the slag content comes to $50 \%$ or more of the cement mass, permeability may be adversely affected unless the mix is suitably cured (2). Song and Saraswathy (68) observed that a $40 \%$ replacement rate had no significant effect on corrosion rates, which were impacted, however, at rates of $60 \%$ or higher. Topçu and Boğa (69) reported both high compressive strength and high steel corrosion resistance in 90-day specimens containing $25 \%$ GBFS. The general consensus is that the reduction in concrete porosity and pore refinement afforded by this addition substantially enhances the resistance to chloride ion ingress (70). Concrete exposed to seawater spray for 25 years, containing high slag replacement rates (45-65\%) and a w/c ratio of 0.40 , was found to successfully resist chloride ion penetration (71). This effect on chloride penetration is attributed to the capacity to bind chlorides (Friedel's salt formation), thereby reducing the ion diffusion coefficient (70, 72, 73). Furthermore, the addition of GBFS, while lowering the $\mathrm{pH}$ in the pore solution, had no adverse effect on steel corrosion (68, 74). ASTM standard C989 (75) lays down recommendations on the use of GBFS in cementitious systems.

Fly ash (FA) is a by-product generated when coal is burnt in boilers, power plants and similar. High quality FA is generally amorphous with spherical particles ranging in size from 10 to $100 \mu \mathrm{m}$. That morphology enhances concrete workability with no need to add water to the mix (2). Adding FA has beneficial effects on some concrete mechanical properties and provides high chloride ion resistance, for it lowers concrete permeability (76-78); as in slag, its effect is attributed to its capacity to bind chlorides thanks primarily to its high alumina content (78). Amapadu et al. (79) reported that partial replacement of cement with FA lowered the chloride diffusion coefficient. These authors suggested an optimal rate of 
contenido de alúmina (78). Amapadu et al. (79) reportan que el reemplazo parcial de cemento por FA reduce el coeficiente de difusión de cloruros y sugiere un porcentaje óptimo del 40\%. Boğa y Topçu (80) afirman que la permeabilidad a cloruros se reduce aún con un reemplazo del 15\%; concuerda esto con lo expresado en diferentes investigaciones $(81,82)$. Burgos et al. (83) comprobaron que adiciones de FA de baja calidad, con contenido de inquemados del $19 \%$, presentan buen comportamiento frente a la corrosión del acero de refuerzo en presencia de cloruros al incorporar un porcentaje del $10 \%$ en la mezcla. Respecto al coeficiente de carbonatación de mezclas de hormigón adicionadas con FA se reporta que el desempeño es función del porcentaje de adición (84). Shi et al. (85) presentan un hormigón de alto desempeño realizado con adiciones de FA y GBFS expuesto a carbonatación, donde concluye que los efectos en la resistencia, la permeabilidad a gases y la profundidad de carbonatación están altamente influenciados por la relación agua/cemento. Al respecto, Qingjun et al. (86) comparan los efectos de FA y GBFS, y afirman que aunque las dos adiciones producen un efecto significativo en la resistencia a la compresión, a igual proporción presenta un mejor desempeño la adición de escoria. Los tipos de FA están especificados en la norma ASTM C618 (87).

Metacaolín (MK): es un material obtenido de la calcinación de la arcilla caolinitica a temperaturas entre $500^{\circ} \mathrm{C}$ a $800^{\circ} \mathrm{C}$. Generalmente su tamaño de partícula es más fino que el del cemento, pero no tan fino como el SF $(2,88)$. La adición del $\mathrm{MK}\left(\mathrm{Al}_{2} \mathrm{Si}_{2} \mathrm{O}_{7}\right)$ en el hormigón tiene ventajas, tales como incrementar la resistencia a compresión y flexión, reducir la permeabilidad, incrementar la resistencia a ataque químico, mejorar la trabajabilidad, reducir la generación de eflorescencias, incrementar la durabilidad, entre otros $(24,89,90)$. La resistencia a la corrosión del acero de refuerzo aumenta con adiciones de MK del 10-15\% aproximadamente $(91,92)$. La presencia de MK reduce ampliamente la difusión de iones cloruro en hormigones adicionados (88, 90, 93-95); por el contrario se reportan resultados controvertidos para el desempeño en presencia de $\mathrm{CO}_{2}(96,97)$. Mejía et al. (98) presentan en su estudio que la profundidad de carbonatación para especímenes adicionados con MK a 28 días de curado son levemente superadas por los hormigones sin adición, y afirman que al incrementar las edades de curado la velocidad de carbonatación se reduce; Vejmelková et al. (99) igualmente comprobaron que los materiales adicionados con MK presentan mejor desempeño a carbonatación. Bai et al. (96) estudian hormigones con adiciones puzolánicas de tipo ternario utilizando FA, cemento Portland y MK, y reportan que los especímenes con menor profundidad de carbonatación corresponden a aquellos que contienen MK. El uso de MK en sistemas cementicios está especificado en la norma ASTM C618 dentro del tipo de puzolanas naturales (87).
40\%. Boğa and Topçu (80) observed that replacement rates as low as $15 \%$ reduced chloride permeability, concurring with findings by other authors $(81,82)$. Burgos et al. (83) found that with a $10 \%$ replacement rate, low quality FA containing 19\% unburnt particles afforded reinforcing steel high corrosion resistance. The carbonation coefficient of concrete mixes made with FA-blended cement has been reported to vary with the replacement rate (84). Shi et al. (85) introduced a high performance concrete made with FA and GBFS additions and exposed to carbonation, concluding that the effects on strength, gas permeability and carbonation depth were heavily impacted by the water/cement ratio. Qingjun et al. (86), comparing the effects of FA and GBFS, noted that although the two additions had a significant effect on compressive strength, slag additions performed better at any given replacement rate. ASTM standard C618 (87) lists the specifications for the various types of $F A$.

Metakaolin (MK) is a material obtained by burning kaolinitic clay at temperatures of 500 to $800{ }^{\circ} \mathrm{C}$. Its particle size is generally finer than in cement, but not as fine as in $\mathrm{SF}(2,88)$. The advantages of adding $\mathrm{MK}\left(\mathrm{Al}_{2} \mathrm{Si}_{2} \mathrm{O}_{7}\right)$ to concrete include enhanced compressive and bending strength, lower permeability, higher chemical resistance, improved workability, lesser efflorescence and longer durability (24, 89, 90). Adding approximately 10-15\% MK raises reinforcing steel corrosion resistance $(91,92)$. The presence of $M K$ reduces chloride ion diffusion substantially in blended cement concretes (88, 90, 93-95), while contradictory results have been reported for its performance in environments containing $\mathrm{CO}_{2}(96,97)$. Mejía et al. (98) observed that the carbonation depth was slightly shallower in 28-day MK-containing specimens than in concretes with no additions, and claimed that at longer curing times the carbonation rate declined; Vejmelková et al. (99) likewise found that MK-blended materials exhibited higher carbonation resistance. Studying concretes containing ternary cements (OPC with FA and MK as pozzolanic additions), Bai et al. (96) reported that the shallowest carbonation depth was found in specimens containing MK. ASTM standard C618 (87) lays down recommendations on the use of $M K$, one of the natural pozzolans, in cementitious systems. 
Existen otros tipos de adiciones puzolánicas, además de las anteriores, y aunque sus estudios han sido limitados ofrecen nuevas alternativas a futuros desarrollos. La cascarilla de arroz, por ejemplo, es un residuo de la industria agrícola que al quemarlo a temperaturas entre $550^{\circ} \mathrm{C}-700^{\circ} \mathrm{C}$ produce ceniza de cascarilla de arroz (RHA), su reactividad es atribuida a su alto contenido de sílice amorfa y gran superficie específica (100). Su incorporación a mezclas cementicias contribuye positivamente a la resistencia a la compresión, Gastaldini et al. (101) reportan un 20\% de RHA como el porcentaje óptimo de reemplazo. Con respecto a la durabilidad de los cementos con adición de RHA se observa una reducción a la penetración del ion cloruro (101-103). Chindaprasirt y Rukzon (104) afirman que cementos ternarios con OPC, RHA y FA mejoran el comportamiento a la corrosión del acero inducida por cloruros. Respecto a la profundidad de carbonatación se observan incrementos con la adición de RHA (105, 106). Otra adición puzolánica es la ceniza de aceite de palma (CAP), esta es un subproducto de las plantas utilizadas para generación de electricidad a partir del aceite de palma, contiene altos porcentajes de sílice (107) y se afirma que puede ser una puzolana, sin embargo, en ocasiones es necesario disminuir el tamaño de partícula para que exista reactividad puzolánica (108). Con una adición de CAP ultra-fina se reduce el porcentaje de porosidad, coeficiente de permeabilidad a agua, gas y cloruros (109). Entre otras nuevas adiciones se encuentra el polvo de residuos de vidrio (PRV), el cual presenta reacción puzolánica y puede ser utilizada igualmente como reemplazo del cemento (110-113), este material contiene principalmente sílice, sin embargo se debe considerar el contenido elevado de álcalis (113). Matos y Sousa-Coutinho (114) reportan que a pesar del contenido de álcali de la adición de PRV se redujo la expansión por ASR; adicionalmente el material en órdenes del $10 \%$ contribuye a incrementar la resistencia al ion cloruro y al ataque por sulfatos. Otra adición que ha venido siendo estudiada en los últimos años, es el catalizador de craqueo catalítico (FCC); este es un residuo de la industria del petróleo, entre sus ventajas se encuentran notables mejoras de las propiedades mecánicas de las mezclas cementicias (115), aunque algunos investigadores reportan mayor susceptibilidad a la carbonatación (116).

No solo las adiciones minerales han contribuido en el campo de la durabilidad del hormigón, aditivos naturales novedosos, como el mucílago de nopal, han sido de interés; Ramírez-Arellanes et al. (117) presentan en su investigación una disminución del coeficiente de difusión de cloruros del $20 \%$ para especímenes de relación solución mucílago/cemento de 0,30; afirman los investigadores que este aditivo adicionalmente modifica la viscosidad y retarda el tiempo de fraguado de las mezclas.
Other types of pozzolanic additions have been identified, and while scantly studied to date, they constitute promising alternatives for the future. Rice husks, for instance, are an agri-industrial waste product that when burnt at temperatures of 550-700 \% C generate rice husk ash (RHA). The reactivity of this product is attributed to its high amorphous silica content and high specific surface (100). Its inclusion in cementitious blends raises compressive strength. Gastaldini et al. (101) observed the optimal replacement rate for RHA to be $20 \%$. Given their lower chloride ion penetration than in unblended cements, RHA-blended cements exhibit longer durability (101-103). Chindaprasirt and Rukzon (104) found that ternary cements containing OPC, RHA and FA improved resistance to chloride-induced corrosion in steel. Carbonation depths were observed to rise with RHA (105, 106). Another pozzolanic addition, palm oil ash (POA), is a by-product of power plants fired with this fuel. It contains high percentages of silica (107) and while claimed to be a pozzolan, on occasion it must be ground to a smaller particle size to be effective. Adding ultrafine POA lowers concrete porosity and with it water, gas and chloride permeability coefficients (109). Waste glass powder (WGP) is another new pozzolanic addition that may be used as a cement replacement (110-113). This material consists primarily of silica, although its high alkali content must also be taken into consideration (113). Matos and Sousa-Coutinho (114) reported that despite the alkali content, adding WGP reduced ASR expansion; in addition, at rates on the order of $10 \%$, it contributes to chloride ion and sulfate resistance. Another addition that has been studied in recent years is fluid catalytic cracking catalyst residue (FC3R). This oil industry waste product substantially improves the mechanical properties of cementitious mixes (115), although some researchers have observed that its use raises concrete vulnerability to carbonation (116).

\footnotetext{
Mineral additions are not the only substances that have contributed to concrete durability: natural admixtures such as Barbary fig mucilage have also aroused interest. Ramírez-Arellanes et al. (117) found that the chloride diffusion coefficient declined by $20 \%$ in specimens containing a mucliage/cement ratio of 0.30 and claimed that this admixture also modified concrete viscosity and retarded setting.
} 


\subsection{Técnicas electroquímicas}

Para extender la vida útil de estructuras afectadas por la corrosión existen técnicas electroquímicas que son utilizadas para prevenir, evitar o rehabilitar las estructuras de hormigón, entre estas: protección catódica, prevención catódica, extracción electroquímica de cloruros y realcalinización electroquímica.

\subsubsection{Protección y prevención catódica}

Protección catódica: es una de las técnicas más antiguas para la protección de la corrosión en ambientes agresivos, ha sido utilizada en la industria petrolera, tanques de almacenamiento, estructuras subterráneas, protección de estructuras de hormigón armado, entre otras (118). Startfull aplicó esta técnica por primera vez en puentes contaminados por sales de deshielo en California en 1973 (7). Esta técnica electroquímica de reparación consiste en la aplicación permanente de corriente directa para proteger el acero de refuerzo. Existen dos tipos principales de protección catódica: protección catódica por corriente impresa (PCCI) y protección catódica por ánodos de sacrificio (PCAS).

La PCCI requiere la aplicación permanente de pequeñas cantidades de corriente directa al acero, para que este trabaje como cátodo y así prevenga al acero de corroerse. Los principales componentes del sistema son: ánodo (ubicado en la superficie de la estructura, basados principalmente en mallas de titanio o pinturas conductivas), acero de refuerzo, electrolito (hormigón), fuente de poder y equipos de monitoreo $(7,119)$. Cabe mencionar que con esta técnica se induce a cambios químicos en el hormigón, la principal reacción se da en la interfaz del acero/hormigón, ocasionando la reducción de oxígeno y la producción de iones hidroxilos, aumentando la alcalinidad del hormigón, por lo cual se considera que el efecto de la PCCI no es solo reducir el proceso de corrosión sino también es responsable de la restauración de la película pasiva $(120,121)$. Se han realizado diversas investigaciones sobre la técnica, principalmente se afirma que es un método efectivo para controlar la corrosión inducida por cloruros y/o carbonatación (7, 121, 122). Christodoulou et al. (123) presentan resultados de una estructura de hormigón armado después de 10 años de servicio a la cual se le aplicó PCCI durante 5 años, y reportan que después de 24 meses de retirada la PCCI el acero continúa en estado pasivo, es decir, sin signos de corrosión. Con respecto a los factores de diseño de PCCI se han estudiado diferentes ánodos externos alternativos, tales como, recubrimientos cementicios fibroreforzados con fibras de carbono (124-127), recubrimientos de matriz polimérica conductora $(128,129)$, entre otros. La densidad de corriente inicial requerida en la PCCI es del orden de 5-15 mA/m² en ciertas condiciones ambientales, por ejemplo donde el acceso a oxígeno es reducido esta densidad de

\subsection{Electrochemical techniques}

Electrotechnical techniques are in place to rehabilitate or prevent corrosion in concrete structures with a view to extending their service life. They include cathodic protection and prevention, electrochemical chloride extraction and electrochemical realkalinisation.

\subsubsection{Cathodic protection and prevention}

Cathodic protection is one of the oldest techniques for combating corrosion in aggressive environments. It has been used in the oil industry, storage tanks, underground construction and as protection for reinforced concrete structures (118). Startfull first applied it on bridges affected by de-icing salts in California in 1973 (7). This electrochemical repair technique consists of permanently applying direct current to protect the reinforcing steel. The two main types of cathodic protection are impressed current cathodic protection (ICCP) and sacrificial anode cathodic protection (SACP).

ICCP involves applying small amounts of direct current to the steel, requiring it to act as a cathode and preventing its corrosion. The chief system components are the anode (located on the surface of the structure and consisting primarily of titanium wire or conductive paint), the reinforcing steel, an electrolyte (concrete), a power source and monitoring equipment $(7,119)$. This technique induces chemical changes in the concrete. The main reaction takes place at the steel/concrete interface, where oxygen reduction and the formation of hydroxyl ions raise concrete alkalinity. Consequently, ICCP not only detains corrosion, but contributes to restoring the passive film $(120,121)$. A number of studies have been conducted on the technique, which has been shown to effectively control chloride- or carbonation-induced corrosion (7, 121, 122). Christodoulou et al. (123) studied a reinforced concrete structure that had been in service for 10 years and to which ICCP had been applied for 5 . They reported that 24 months after the ICCP had been removed, the steel continued to be in a passive state, i.e., with no signs of corrosion. Different external anodes, such as carbon fibrereinforced cementitious covers (124-127) and conductive polymer matrices $(128,129)$ have been used in ICCP design. The current density required in ICCP is on the order of $5-15 \mathrm{~mA} / \mathrm{m}^{2}$ in certain environmental conditions, although where access to oxygen is limited, current density may be as low as 0.2 to $2 \mathrm{~mA} / \mathrm{m}^{2}$, and once the steel is passivated, the current density used is $2-5 \mathrm{~mA} / \mathrm{m}^{2}$ (7). The drawbacks to this technique are its high maintenance and installation costs (119) and 
corriente puede ser del orden de 0,2 a $2 \mathrm{~mA} / \mathrm{m}^{2}$; cuando se alcanza la pasivación del acero la densidad de corriente utilizada es 2-5 mA/m² (7). Las desventajas de esta técnica son su alto costo de mantenimiento e instalación (119) y no es recomendable utilizarla en hormigón pretensado por el riesgo de fragilización por hidrógeno (7).

La PCAS se basa principalmente en conectar la estructura a un material más activo que el acero, el cual actuará como ánodo de sacrificio. Entre las características de este ánodo están: tener un potencial muy negativo capaz de proteger el acero de refuerzo, no desarrollar películas pasivantes protectoras y presentar corrosión uniforme (130). Los ánodos de sacrificio más utilizados son de aluminio, zinc, magnesio y sus aleaciones, entre estas figuran aleaciones Al-Zn-In, aleaciones magnesio con contenidos bajos de manganeso, entre otras (131-136). Una nueva técnica que se encuentra en vías de desarrollo es la protección catódica por ánodos discretos (ánodos embebidos en el hormigón); Moreno et al. (130) concluyeron que el acero se protegió catódicamente con ánodos discretos de zinc, sin embargo se lixiviaron los productos de corrosión de los ánodos por la alta humedad relativa. Sergi y Whitmore (137) embebieron ánodos de zinc en el puente de Leicester (Reino Unido), y lo monitorearon por 10 años no observando lixiviación, aunque después de desconectar los ánodos se incrementa la velocidad de corrosión. La PCAS es de fácil instalación y de bajo costo en comparación con PCCI, su principal desventaja es la vida en servicio de los ánodos, los cuales deben ser cambiados cada que se desgasten.

Prevención catódica: para los casos de estructuras nuevas que vayan a estar expuestas a cloruros o carbonatación se puede aplicar prevención catódica, técnica presentada por Pedeferri como un método preventivo de mantenimiento (138). Esta técnica de prevención se encuentra influenciada directamente por el umbral de contenido de cloruros en la estructura, ya que para decir que se está aplicando prevención catódica no se debe haber alcanzado dicho umbral (121). En este caso, se aplican bajas densidades de corriente del orden $0,5-2 \mathrm{~mA} / \mathrm{m}^{2}$, es decir, en condiciones que el acero de refuerzo este pasivado. Esta técnica ayuda a incrementar el umbral de contenido de cloruros antes de que se inicie la corrosión, y así mantener el acero de refuerzo en condiciones pasivas, aún en presencia de altos contenidos de cloruros. Cabe anotar, que en hormigones pretensados no es recomendable aplicar este método por la posibilidad de fragilización por hidrógeno (139).

\subsubsection{Extracción electroquímica de cloruros (EEC)}

Como su nombre indica, el objetivo de esta técnica es lograr extraer los iones cloruros de la estructura. Este método es similar al de protección catódica, a diferencia its incompatibility with prestressed concrete due to possible hydrogen embrittlement (7).

SACP is based primarily on connecting the structure to a more active material than steel, able to act as a sacrificial anode. The characteristics of this anode include: a very negative potential able to protect the reinforcing steel, the non-development of protective passivating films, and uniform corrosion (130). The most widely used sacrificial anodes are aluminium, zinc and magnesium and their alloys, including Al-Zn-In alloys and magnesium alloys with a low manganese content (131-136). A new technique currently under development is cathodic protection with discrete anodes (anodes embedded in the concrete); Moreno et al. (130) concluded that discrete zinc anodes cathodically protected steel, although the anode corrosion products were leached out in high relative humidity. Sergi and Whitmore (137) embedded zinc anodes in Leicester Bridge in the United Kingdom and monitored the structure for 10 years. They observed no leaching, although after the anodes were disconnected the corrosion rate rose. SACP is readily installed and lower in cost than ICCP. Its main drawback is the short service life of the anodes, which must be replaced when worn.

Cathodic prevention can be used in new structures exposed to chlorides or carbonation. This technique, introduced by Pedeferri, is a preventive maintenance measure (138). It is directly related to the threshold content of chlorides in the structure, for cathodic prevention can only be said to be in place if that threshold is not reached (121). Here, low current densities on the order of $0.5-2 \mathrm{~mA} / \mathrm{m}^{2}$ are applied in conditions in which the reinforcing steel is passivated. This technique helps raise the threshold content of chlorides before corrosion sets in and thereby maintains the reinforcing steel in a passive state, even in the presence of high chloride contents. This method is not recommended for prestressed concrete due to the possible appearance of hydrogen embrittlement (139).

\subsubsection{Electrochemical chloride extraction (ECE)}

As may be inferred from its name, this technique is designed to extract chloride ions from the structure. The method is similar to cathodic protection, except that it 
que se aplica temporalmente una corriente de mayor intensidad para forzar a los iones cloruros a migrar hacia el ánodo, el cual se ubica sobre la superficie del hormigón (140). Esta técnica es utilizada para las estructuras contaminadas por cloruros, bien sea por estar expuestas a ambientes marinos, sales de deshielo, entre otros.

En EEC se aplica una corriente directa entre el acero de refuerzo y el ánodo externo, el cual está en contacto con un electrolito (solución saturada de hidróxido de calcio o agua potable); la aplicación de la corriente genera el campo eléctrico necesario para que los iones cloruro sean extraídos hacia el ánodo externo, y los iones de carga negativa $(\mathrm{OH}-)$ ingresen hacia el cátodo (acero de refuerzo) (140-143). Debido a las altas densidades de corriente aplicadas $1-2 \mathrm{~A} / \mathrm{m}^{2}$, esta técnica debe ser utilizada por un tiempo corto, usualmente de 6 a 10 semanas (7).

La posibilidad de extraer cloruros empieza a ser estudiada en la década de los 70s en los Estados Unidos, sin embargo, en Europa fue patentado por una compañía noruega NORCURE® en 1986 (7). En estudios de laboratorio en relación con la eficiencia del método, Orellan et al. (144) afirman que aplicando una densidad de corriente de $1 \mathrm{~A} / \mathrm{m}^{2}$, malla de titanio como ánodo y un electrolito de hidróxido de calcio, se logra extraer del $40-45 \%$ de cloruros de los especímenes después de 50 días de realizado la EEC. Abdelaziz et al. (145) aplican las mismas condiciones y reportan una extracción del $30 \%$ de cloruros después de 30 días de aplicado el tratamiento. Rodríguez et al. (146) logran extraer un $37 \%$ de cloruros a 60 días de aplicado el tratamiento, además concluyen que la cantidad de cloruros removidos de los especímenes se incrementa con el tiempo de duración del EEC, y no es significativo el efecto de incrementar la densidad de corriente a $2 \mathrm{~A} / \mathrm{m}^{2}$. Fajardo et al. (147) lograron reducir el contenido de cloruros en un $30 \%$ a una profundidad de $5 \mathrm{~cm}$, mientras que a una profundidad de $2 \mathrm{~cm}$ se redujo en un $75 \%$ después de 90 días de aplicado la EEC. En general, se recomienda para medir la eficiencia del tratamiento de EEC esperar aproximadamente unas 4 semanas después de realizado el proceso, esto con el fin que la estructura se estabilice y se pueda considerar rehabilitado (145).

Con respecto a los tipos de cloruros presentes en el hormigón, los cloruros enlazados oponen mayor resistencia a su extracción, por lo tanto, hormigones con alto contenido de $C_{3} A$ requieren una mayor densidad de corriente para lograr la eficiencia de la EEC, sin embargo, a mayores densidades de corriente podría ocurrir una descomposición en la pasta del cemento $(140,148$, 149). En resumen, el tratamiento puede ser ineficiente si el porcentaje de cloruros libres es muy bajo (149). Para hormigones con relaciones agua/cemento bajas y un espesor de recubrimiento mayor de hormigón se involves the temporary application of a higher intensity current to force the chloride ions to migrate toward the anode, positioned on the concrete surface (140). This technique is used for chloride-contaminated structures in marine environments or affected by de-icing salts.

In ECE, a direct current is applied between the reinforcing steel and the outer anode, which is in contact with an electrolyte (calcium hydroxide-saturated solution or drinking water). This generates the electrical field required to attract the chloride ions to the outer anode, while the negatively charged ions $\left(\mathrm{OH}^{-}\right)$migrate toward the cathode (reinforcing steel) (140-143). Due to the high current densities required (1-2 $\left.\mathrm{A} / \mathrm{m}^{2}\right)$, this technique should only be applied for short periods, usually from 6 to 10 weeks (7).

Although the possibility of extracting chlorides began to be studied in the United States in the nineteen seventies, the system was patented in Europe by a Norwegian company, NORCURER, in 1986 (7). In laboratory studies to assess the effectiveness of the method, Orellan et al. (144) observed that using a current density of $1 \mathrm{~A} / \mathrm{m}^{2}$, titanium wire as the anode and calcium hydroxide as the electrolyte, $40-45 \%$ of the chlorides were removed from the specimens after 50 days of ECE treatment. Abdelaziz et al. (145), working under the same conditions, reported that $30 \%$ of the chlorides were extracted after 30 days. Rodríguez et al. (146) extracted $37 \%$ of the chlorides after 60 days of ECE and concluded that the amount of chlorides removed from the specimens grew with treatment duration, while the effect of raising the current density to $2 \mathrm{~A} / \mathrm{m}^{2}$ had no significant effect on the results. Fajardo et al. (147) lowered the chloride content by $30 \%$ at a depth of $5 \mathrm{~cm}$ and by $75 \%$ at a depth of $2 \mathrm{~cm}$ after 90 days of ECE. As a rule, ECE effectiveness measurements should be made approximately 4 weeks after completion of the procedure, when the structure has stabilised, allowing for a truer assessment of its rehabilitation (145).

Bound chlorides are more difficult to extract. Consequently, concretes with a high $C_{3} A$ content need a higher current density for ECE to be effective. Nonetheless, at high current densities, the cement paste may disintegrate $(140,148,149)$. In other words, the treatment may be ineffective if the free chloride content is very low (149). 
requiere más densidad de corriente y tiempo aplicado, si se compara con hormigones con relaciones de agua/ cemento más altas y espesores más pequeños (141, $143,150,151)$.

El tratamiento de EEC es capaz de remover cloruros de la estructura, sin embargo, no puede detener el daño si el deterioro es avanzado (151), es por ello que se considera un método preventivo más no un método de rehabilitación (152); adicionalmente este método no es capaz de repasivar el acero de refuerzo (146, 147, 152). Algunos autores reportan efectos secundarios después de aplicado el tratamiento tales como la reacción álcali-sílice bajo condiciones de exposición de los especímenes a una humedad relativa del $100 \%$ y temperaturas de $60{ }^{\circ} \mathrm{C}$ (144).

En investigaciones recientes, Sánchez y Alonso (153) proponen el uso del inhibidor nitrito de calcio durante el tratamiento de EEC, logrando extraer un 35\% de cloruros e incluir el inhibidor al nivel del acero de refuerzo para garantizar una pasivación más rápida y eficiente. Pérez et al. (154) presentan un ánodo externo alternativo denominado pasta de cemento conductiva, este reporta una eficiencia similar a la obtenida con el ánodo de malla de titanio clásico, pero podría reportar daños durante la EEC debido a la acidez producida por las reacciones anódicas.

\subsubsection{Realcalinización electroquímica (RE)}

La RE es una técnica muy similar a la EEC, su objetivo es restablecer la alcalinidad del hormigón que se ha perdido por acciones de agentes atmosféricos y/o químicos que han propiciado el proceso de carbonatación en la estructura (155).

La técnica consiste en la aplicación de una corriente directa, generándose un campo eléctrico entre el acero de refuerzo (cátodo) y un ánodo externo en presencia de una solución alcalina llamada electrolito, usualmente se utiliza carbonato de sodio $\left(\mathrm{Na}_{2} \mathrm{CO}_{3}\right)$. Es una técnica temporal debido a las altas densidades de corriente aplicadas 1-2 A/m², usualmente de 3-21 días $(7,142)$. En el sistema se generan reacciones químicas: en el cátodo se evidencia la producción de iones hidroxilo [14], por lo cual el valor del $\mathrm{pH}$ alrededor del acero de refuerzo se incrementa; igualmente se genera hidrógeno, y si el potencial aplicado es muy negativo podría producirse fragilización por hidrógeno $(142,156)$. En el ánodo se da lugar a la transformación de hidroxilos en oxígeno y agua acorde a [15].
Higher current densities and longer treatment times are required in concretes with low water/cement ratios and thicker concrete covers than in concretes with higher water/cement ratios and shallower covers (141, 143, 150, 151).

While ECE treatment can remove chlorides from the structure, it is unable to curb severe deterioration (151). It is therefore regarded more as a preventive than a rehabilitation method (152); nor is it able to repassivate reinforcing steel (146, 147, 152). Some authors have reported side effects after applying the treatment, such as the alkali-silica reaction in specimens exposed to $100 \%$ relative humidity and a temperature of $60^{\circ} \mathrm{C}$ (144).

In recent research, Sánchez and Alonso (153) proposed the use of a calcium nitrite inhibitor in conjunction with ECE. They extracted 35\% of the chlorides and sank the inhibitor to the depth of the reinforcing steel to guarantee speedier and more effective passivation. Pérez et al. (154) proposed an alternative external anode called conductive cement paste. While it was approximately as effective as traditional titanium wire, the acidity generated during the anodic reactions could potentially damage the steel.

\subsubsection{Electrochemical realkalinisation (ER)}

A technique similar to EEC, ER aims to restore the alkalinity lost in the concrete due to the action of the atmospheric or chemical agents that induce carbonation in the structure (155).

It consists of applying a direct current to create an electrical field between the reinforcing steel (cathode) and an external anode in the presence of an alkaline electrolyte, usually a sodium carbonate $\left(\mathrm{Na}_{2} \mathrm{CO}_{3}\right)$ solution. Its application is short term, generally from 3 to 21 days, due to the high current densities needed (1-2 $\left.\mathrm{A} / \mathrm{m}^{2}\right)$. Chemical reactions take place in the system: hydroxyl ions [14] form in the cathode, raising the $\mathrm{pH}$ in the area surrounding the reinforcing steel. As hydrogen is likewise generated, and if the potential applied is very negative, hydrogen embrittlement may also appear (142, 156). In the anode, hydroxyls are converted into oxygen and water as in [15].

$$
\begin{gathered}
2 \mathrm{H}_{2} \mathrm{O}+2 \mathrm{e}^{-} \rightarrow \mathrm{H}_{2}+2 \mathrm{OH}^{-} \\
2 \mathrm{OH}^{-} \rightarrow 1 / 2 \mathrm{O}_{2}+\mathrm{H}_{2} \mathrm{O}+2 \mathrm{e}^{-}
\end{gathered}
$$


El electrolito alcalino que se encuentra presente en la superficie de la estructura penetra al interior del hormigón, donde se presenta la reacción [16]:
The alkaline electrolyte present on the surface of the structure penetrates into the concrete, where it reacts as shown in [16]:

$$
\mathrm{Na}_{2} \mathrm{CO}_{3}+\mathrm{CO}_{2}+\mathrm{H}_{2} \mathrm{O} \rightarrow 2 \mathrm{NaHCO}_{3}
$$

Así, el ingreso del carbonato de sodio en la estructura actúa como captador de dióxido de carbono presente en ella (157).

Esta técnica fue desarrollada a finales de la década de los 80 por John Miller en Noruega, a partir de allí ha sido utilizada principalmente en el norte de Europa (142). Respecto a la eficiencia, Yeih y Chang (157) afirman que esta técnica incrementa los valores de $\mathrm{pH}$ cerca al acero de refuerzo (alrededor de 11), mientras la resistencia a la compresión, el módulo elástico y la adherencia al hormigón disminuyen linealmente a medida que la corriente pasante y el tiempo aumentan.

La aplicación de RE en hormigones con adiciones puzolánicas es exitoso, sin embargo estos requieren mayor densidad de carga pasante para poder realcalinizar toda la estructura (155). Otro factor importante es la relación agua/cemento, se reporta que a mayores relaciones el espesor del hormigón realcalinizado es superior (155, 158); a su vez en presencia de relaciones agua/cemento reducidas es necesario mayor densidad de corriente y tiempo de tratamiento (155). Respecto al efecto de diferentes electrolitos, tales como, hidróxido de calcio, hidróxido de potasio, carbonato de sodio, carbonato de potasio, se reportan como de mayor eficacia en la RE el carbonato de sodio y el hidróxido de potasio (159). Cabe anotar que algunos investigadores afirman que el $\mathrm{K}_{2} \mathrm{CO}_{3}$ tiende a mantener una mayor alcalinidad en la región anódica comparado con el $\mathrm{Na}_{2} \mathrm{CO}_{3}$, y el concreto reforzado requiere menor voltaje aplicado debido a la mayor movilidad y conductividad de los iones $\mathrm{K}^{+}$comparado a los iones $\mathrm{Na}^{+}$, a la par que existe menor riesgo de eflorescencias (160).

De los estudios realizados en el tema se puede inferir que el método de realcalinización puede resolver el problema de carbonatación en hormigón armado, extendiendo la vida útil (142, 155-162), sin embargo, se sugiere utilizar esta técnica como un método preventivo, es decir, antes que la corrosión haya alcanzado a la armadura $(159,163)$, ya que no está claro que se genere una repasivación de las barras de acero (161).

\section{CONCLUSIONES}

Esta revisión bibliográfica muestra que la durabilidad del hormigón armado está influenciada por distintos factores, algunos de ellos relacionados al material y otros de
The sodium carbonate flowing into the structure therefore captures the carbon dioxide present (157).

This technique was developed in the nineteen eighties in Norway by John Miller and has since been used primarily in northern Europe (142). Yeih and Chang (157) claimed that it raised the $\mathrm{pH}$ around the reinforcing steel (to values of about 11), whereas compressive strength, the modulus of elasticity and concrete bonding declined linearly with rising current intensities and treatment times.

ER has been successfully applied to concretes with pozzolanic additions, although in this case a higher charge density was required to realkalinise the entire structure (155). Another important factor is the water/cement ratio: the higher the ratio, the deeper the realkalinisation depth $(155,158)$, while concrete with lower water/ cement ratios call for higher current densities and treatment times (155). Sodium carbonate and potassium hydroxide have been identified as the most effective ER electrolytes (159). Of the various possible electrolytes, including calcium hydroxide, potassium hydroxide, sodium carbonate and potassium carbonate, the two most effective for the intents and purposes of ER are sodium carbonate and potassium hydroxide (159). Some researchers contend that $\mathrm{K}_{2} \mathrm{CO}_{3}$ tends to keep the anode region more alkaline than $\mathrm{Na}_{2} \mathrm{CO}_{3}$, that the greater $\mathrm{K}^{+}$ ion than $\mathrm{Na}^{+}$ion mobility and conductivity calls for lower voltage in the reinforced concrete and that the risk of efflorescence is lower with potassium (160).

The studies conducted on the subject indicate that realkalinisation can solve the carbonation problem in reinforced concrete, extending its service life (142, 155162), although this technique is suggested for use as a preventive method only, i.e., before corrosion affects the reinforcement $(159,163)$, for it has not been shown to repassivate steel rebar (161).

\section{CONCLUSIONS}

This bibliographic review shows that reinforced concrete durability is affected by a number of factors, some environmental and others associated with the material. 
carácter ambiental, factores que deben ser considerados en el momento del diseño y construcción de la estructura por lo cual es imperativo el cumplimiento de los códigos constructivos de cada país. Asimismo se enfatiza sobre los factores desencadenantes de la corrosión en el acero estructural, la inclusión de cloruros y la carbonatación, para finalmente mostrar los diferentes métodos que pueden ser aplicados con el objetivo de prevenir y controlar la corrosión del acero de refuerzo. Entre estos, la adición de materiales minerales tipo puzolanas como reemplazo parcial del cemento generalmente mejora la resistencia a la penetración por cloruros, pero en pocos casos reduce el frente de carbonatación. Por el contrario, las técnicas electroquímicas son métodos efectivos que pueden ser aplicados en los diferentes casos, aunque cabe resaltar que RE y EEC son técnicas preventivas útiles que pueden extender la vida útil del acero cuando el efecto sobre este no es altamente significativo, mientras PC permite detener el proceso corrosivo. La elección final de la técnica o técnicas a aplicar en cada caso es función del análisis del problema o falla presentada, el conocimiento del estado de la estructura y las facilidades técnicas y económicas de su implementación.
These factors must be taken into consideration during structural design and construction, and national building codes must be heeded. The review places special emphasis on the factors that drive corrosion in structural steel, namely chloride ingress and carbonation, and discusses the prevention and control methods in place. These include the addition of pozzolanic minerals as partial cement replacements, which as a rule raise chloride penetration resistance but seldom reduce the carbonation front. Electrochemical techniques are effective in a number of situations, although ER and ECE are useful preventive measures that can extend the service life of steel when it has not been significantly impacted. $C P$, in turn, is able to detain the corrosive process. The final choice of a technique or techniques to be applied in each case depends on the analysis of the problem or weakness observed, the information available on the state of the structure and the technical and financial implications of the procedure chosen.

\section{BIBLIOGRAFÍA / BIBLIOGRAPHY}

(1) Fajardo, G.; Váldez, P.; Pacheco, J.: "Corrosion of steel rebar embedded in natural pozzolan based mortars exposed to chlorides", Constr. Build. Mater., vol. 23, n0 2 (2009), pp. 768-74.

(2) Shi, X.; Xie, N.; Fortune, K.; Gong, J.: "Durability of steel reinforced concrete in chloride environments: An overview", Constr. Build. Mater., vol. 30, n⿳0 0 (2012), pp. 125-38.

(3) Mejía, R.; Rodríguez, P.: Durabilidad y Corrosión en Materiales Cementicios, CYTED, Costa Rica (1999).

(4) Neville, A.: "Consideration of durability of concrete structures: Past, present, and future", Mat. Struct., vol. $34, \mathrm{n}^{0} 2$ (2001), pp. 114-8.

(5) Ahmad, S.: "Reinforcement corrosion in concrete structures, its monitoring and service life prediction-a review", Cem. Concr. Comp., vol. 25, n0 4-5 (2003), pp. 459-71.

(6) Mehta, P. K.; Monteiro, P. J. M.: Concrete Microstructure, Properties, and Materials, McGraw Hill, New York (2006).

(7) Bertolini, L.; Elsener, B.; Pedeferri, P.; Polder, R.: Corrosion of Steel in Concrete, WILEY-VCH Verlag GmbH \& Co, Weinheim (2004).

(8) Tanesi, J.; Meininger, R.: "Freeze-Thaw Resistance of Concrete with marginal air content", Research, Development, and Technology Federal Highway Administration, vol. no 0 (2006), pp. 1-78.

(9) EN206-1 "Hormigón - Parte 1: Especificación, comportamiento, fabricación y conformidad". CEN (2000).

(10) ASTM-C666/C666M-03 "Standard Test Method for Resistance of Concrete to Rapid Freezing and Thawing". ASTM Standards (2008).

(11) ACI-201.2R-01 "Guide to Durable Concrete". Committee 201 (2001).

(12) Hossain, K. M. A.; Lachemi, M.: "Performance of volcanic ash and pumice based blended cement concrete in mixed sulfate environment", Cem. Concr. Res., vol. 36, no 6 (2006), pp. 1123-33.

(13) Sanjuán, M. A.; Argiz, C.: "La nueva norma europea de especificaciones de cementos comunes UNE-EN 197-1:2011", Mater. Construcc., vol. 62, n0 307 (2012), pp. 425-30.

(14) Márquez, G.; Alejandre, F. J.; Martín-del-Río, J. J.; Arribas, R.; Blasco, F. J.: "Ataque del anhídrido carbónico y el ácido sulfhídrico sobre pastas de cemento API clase H expuestas a aguas de formación salina", Mater. Construcc., vol. 61, n 303 (2011), pp. 371-84.

(15) Sideris, K. K.; Savva, A. E.; Papayianni, J.: "Sulfate resistance and carbonation of plain and blended cements", Cem. Concr. Comp., vol. 28, n0 1 (2006), pp. 47-56.

(16) Rodríguez-Camacho, R. E.; Uribe-Afif, R.: "Importance of using the natural pozzolans on concrete durability", Cem. Concr. Res., vol. 32, no 12 (2002), pp. 1851-8.

(17) Karakurt, C.; Topçu, İ. B.: "Effect of blended cements produced with natural zeolite and industrial by-products on alkali-silica reaction and sulfate resistance of concrete", Constr. Build. Mater., vol. 25, no 4 (2011), pp. 1789-95.

(18) Al-Akhras, N. M.: "Durability of metakaolin concrete to sulfate attack", Cem. Concr. Res., vol. 36, no 9 (2006), pp. 1727-34. 
(19) Najimi, M.; Sobhani, J.; Pourkhorshidi, A. R.: "Durability of copper slag contained concrete exposed to sulfate attack", Constr. Build. Mater., vol. 25, n0 4 (2011), pp. 1895-905.

(20) Irassar, E. F.; Sota, J. D.; Batic, O. R.: "Evaluación de la resistencia a los sulfates de cemento con ceniza volante (utilizando el método de Koch \& Steinegger)", Mater. Construcc., vol. 38, n 212 (1988), pp. 21-35.

(21) ASTM-C1012/C1012M "Test Method for Length Change of Hydraulic-Cement Mortars Exposed to a Sulfate Solution". ASTM Standars (2012).

(22) ASTM-C1157/C1157M "Standard Performance Specification for Hydraulic Cement". ASTM Standars (2011).

(23) Sims, I.; Brown, B. 16 - Concrete Aggregates, Lea's Chemistry of Cement and Concrete (Fourth Edition), Butterworth-Heinemann, Oxford, pp. 907-1015 (2003).

(24) Olague, C.; Wenglas, G.; Castro, P.: "Influencia de los álcalis provenientes de fuentes distintas al cemento en la evolución de la reacción álcali-sílice", Mater. Construcc., vol. 53, n0 271-272 (2003), pp. 189-98.

(25) Lindgård, J.; Andiç-Çakır, Ö.; Fernandes, I.; Rønning, T. F.; Thomas, M. D. A.: "Alkali-silica reactions (ASR): Literature review on parameters influencing laboratory performance testing", Cem. Concr. Res., vol. 42, n' 2 (2012), pp. 223-43.

(26) ASTM-C295/C295M "Standard Guide for Petrographic Examination of Aggregates for Concrete". ASTM Standars (2012).

(27) Sims, I.; Nixon, P.: "RILEM recommended test method AAR-1: Detection of potential alkali-reactivity of aggregates-Petrographic method", Mat Struct, vol. 36, n0 7 (2003), pp. 480-96.

(28) ASTM-C289 "Standard Test Method for Potential Alkali-Silica Reactivity of Aggregates (Chemical Method)". ASTM Standars (2007).

(29) Foradada, J. S.: Envejecimiento de presas por reacciones expansivas en hormigón, Universitat Politècnica de Catalunya, Barcelona (2005).

(30) ASTM-C1293-08b "Test Method for Determination of Length Change of Concrete Due to Alkali-Silica Reaction". ASTM Standards (2008).

(31) ASTM-C227 "Standard Test Method for Potential Alkali Reactivity of Cement-Aggregate Combinations (Mortar-Bar Method)". ASTM Standards (2010).

(32) Moreno, A. d. V.; López, T. P.; Madrid, M. M.: "El fenómeno de la corrosión en estructuras de concreto reforzado ", Instituto Mexicano del Transporte, vol. 182, $\mathrm{n}^{\mathrm{O}}$ (2001), pp. 1-73.

(33) Américo, P. O.; Nepomuceno, A. A.: "Influencia del contenido en cemento en la corrosión de la armadura en morteros carbonatados", Mater. Construcc., vol. 53, n 271-272 (2003).

(34) López, W.; Feliu, S.; J. González, J.; Andrade, M. C.: "La importancia del curado en el comportamiento posterior frente a la corrosión de las estructuras de hormigón armado", Mater. Construcc., vol. 41, nº 223 (1991), pp. 5-17.

(35) El-Reedy, M. A.: Steel-Reinforced Concrete Structures, CRC Press Taylor \& Francis Group, Boca Raton (2008).

(36) Song, G.; Shayan, A.: "Corrosion of steel in concrete: causes, detection and prediction state-of-the-art Review", ARRB Tranport Research Ltd Australia, vol. 4, $\mathrm{n}^{\mathrm{O}}$ (1998), pp. 1-77.

(37) Nasser, A.; Clément, A.; Laurens, S.; Castel, A.: "Influence of steel-concrete interface condition on galvanic corrosion currents in carbonated concrete", Corrosion Science, vol. 52, n0 9 (2010), pp. 2878-90.

(38) Alexander, M. G.; Mackechnie, J. R.; Yam, W.: "Carbonation of concrete bridge structures in three South African localities", Cem. Concr. Comp., vol. 29, n० 10 (2007), pp. 750-9.

(39) Carmona, T. G.: Modelos de previsão da despassivação das armaduras em estruturas de concreto sujeitas à carbonatação, Universidade de São Paulo, São Paulo (2005).

(40) Otieno, M.; Alexander, M.; Beushausen, H.: "Transport mechanisms in concrete. Corrosion of steel in concrete (initiation, propagation \& factors affecting)". University of Cape Town (2010).

(41) Castro, P.; Sanjuán, M. A.; Genescá, J.: "Carbonation of concretes in the Mexican Gulf", Build. Environ., vol. 35, n 2 (2000), pp. 145-9.

(42) Alonso, C.; Andrade, C.: "Efecto que el tipo de cemento y la dosificación del mortero ejercen en la velocidad de corrosión de armaduras embebidas en mortero carbonatado", Mater. Construcc., vol. 37, nº 205 (1987), pp. 5-15.

(43) Moreno, E. I.; Domínguez, G. G.; Sarabia, E. J. C.; Duarte, F.: "Efecto de la relación agua/cemento en la velocidad de carbonatación del concreto utilizando una cámara de aceleración", Ingeniería, vol. 8, no 2 (2004), pp. 117-30.

(44) Sisomphon, K.; Franke, L.: "Carbonation rates of concretes containing high volume of pozzolanic materials", Cem. Concr. Res., vol. $37, \mathrm{n}^{\circ} 12$ (2007), pp. 1647-53.

(45) UNE.112011 "Corrosión en armaduras. Determinación de la profundidad de carbonatación en hormigones endurecidos y puestos en servicio.". AENOR (1994).

(46) CCAA "Chloride Resistance of Concrete". Cem. Concr. Aggr. Australia (2009).

(47) Song, H.-W.; Lee, C.-H.; Ann, K. Y.: "Factors influencing chloride transport in concrete structures exposed to marine environments", Cem. Concr. Comp., vol. 30, no 2 (2008), pp. 113-21.

(48) Princigallo, A.: "Cálculo del transporte de cloruros en la pasta de cemento", Mater. Construcc., vol. 62, n0 306 (2012), pp. 15161.

(49) Angst, U.; Elsener, B.; Larsen, C. K.; Vennesland, Ø.: "Critical chloride content in reinforced concrete-A review", Cem. Concr. Res., vol. 39, no 12 (2009), pp. 1122-38. 
(50) Díaz-Benito, B.; Velasco, F.; Guzmán, S.; Calabrés, R.: "Estudio mediante AFM de la corrosión de aceros en disoluciones de fase acuosa del hormigón", Mater. Construcc., vol. 61, n0 301 (2011), pp. 27-37.

(51) Güneyisi, E.; Özturan, T.; Gesog `lu, M.: "Effect of initial curing on chloride ingress and corrosion resistance characteristics of concretes made with plain and blended cements", Build. Environ., vol. 42, nº 7 (2007), pp. 2676-85.

(52) ASTM-C1202 "Standard Test Method for Electrical Indication of Concrete's Ability to Resist Chloride Ion Penetration". ASTM Standards (2010).

(53) Al-Amoudi, O. S. B.; Maslehuddin, M.; Lashari, A. N.; Almusallam, A. A.: "Effectiveness of corrosion inhibitors in contaminated concrete", Cem. Concr. Comp., vol. 25, n0 4-5 (2003), pp. 439-49.

(54) Söylev, T. A.; Richardson, M. G.: "Corrosion inhibitors for steel in concrete: State-of-the-art report", Constr. Build. Mater., vol. 22, n0 4 (2008), pp. 609-22.

(55) Selvaraj, R.; Selvaraj, M.; Iyer, S. V. K.: "Studies on the evaluation of the performance of organic coatings used for the prevention of corrosion of steel rebars in concrete structures", Progress in Organic Coatings, vol. 64, n0 4 (2009), pp. 454-9.

(56) Jalili, M. M.; Moradian, S.; Hosseinpour, D.: "The use of inorganic conversion coatings to enhance the corrosion resistance of reinforcement and the bond strength at the rebar/concrete", Constr. Build. Mater., vol. 23, n0 1 (2009), pp. 233-8.

(57) Kepler, J. L.; Darwin, D.; Locke, C. E. "Evaluation of corrosion protection methods for reinforced concrete highway structures". University of Kansas Center for Research (2000).

(58) Batis, G.; Pantazopoulou, P. "Advantages of the simultaneous use of corrosion inhibitors and inorganic coatings". Cement and Concrete Technology in the 2000s Second International Symposium (2000).

(59) Moon, H. Y.; Shin, D. G.; Choi, D. S.: "Evaluation of the durability of mortar and concrete applied with inorganic coating material and surface treatment system", Constr. Build. Mater., vol. 21, n 2 (2007), pp. 362-9.

(60) Zhang, Z.; Yao, X.; Zhu, H.: "Potential application of geopolymers as protection coatings for marine concrete: I. Basic properties", Applied Clay Science, vol. 49, n⿳0 1-2 (2010), pp. 1-6.

(61) Song, H.-W.; Pack, S.-W.; Nam, S.-H.; Jang, J.-C.; Saraswathy, V.: "Estimation of the permeability of silica fume cement concrete", Constr. Build. Mater., vol. 24, n0 3 (2010), pp. 315-21.

(62) Khan, M. I.; Siddique, R.: "Utilization of silica fume in concrete: Review of durability properties", Resources, Conservation and Recycling, vol. 57, n0 0 (2011), pp. 30-5.

(63) Shekarchi, M.; Rafiee, A.; Layssi, H.: "Long-term chloride diffusion in silica fume concrete in harsh marine climates", Cem. Concr. Comp., vol. 31, n0 10 (2009), pp. 769-75.

(64) Thomas, M. D. A.; Hooton, R. D.; Scott, A.; Zibara, H.: "The effect of supplementary cementitious materials on chloride binding in hardened cement paste", Cem. Concr. Res., vol. 42, n 1 (2012), pp. 1-7.

(65) Kulakowski, M. P.; Pereira, F. M.; Molin, D. C. C. D.: "Carbonation-induced reinforcement corrosion in silica fume concrete", Constr. Build. Mater., vol. 23, n0 3 (2009), pp. 1189-95.

(66) ASTM-C1240 "Standard Specification for Silica Fume Used in Cementitious Mixtures". ASTM Standards (2012).

(67) Osborne, G. J.: "Durability of Portland blast-furnace slag cement concrete", Cem. Concr. Comp., vol. 21, n 1 (1999), pp. $11-21$.

(68) Song, H.-W.; Saraswathy, V.: "Studies on the corrosion resistance of reinforced steel in concrete with ground granulated blastfurnace slag-An overview", Journal of Hazardous Materials, vol. 138, n 2 (2006), pp. 226-33.

(69) Topçu, İ. B.; Boğa, A. R.: "Effect of ground granulate blast-furnace slag on corrosion performance of steel embedded in concrete", Materials \&amp; Design, vol. 31, $\mathrm{n}^{0} 7$ (2010), pp. 3358-65.

(70) Chen, H.-J.; Huang, S.-S.; Tang, C.-W.; Malek, M. A.; Ean, L.-W.: "Effect of curing environments on strength, porosity and chloride ingress resistance of blast furnace slag cement concretes: A construction site study", Constr. Build. Mater., vol. 35, n 0 (2012), pp. 1063-70.

(71) Thomas, M. D. A.; Scott, A.; Bremner, T.; Bilodeau, A.; Day, D.: "Performance of Slag Concrete in Marine Environment", ACI Materials Journal, vol. 105, n⿳0 6 (2008), pp. 628-34.

(72) Yiğiter, H.; Yazıcı, H.; Aydın, S.: "Effects of cement type, water/cement ratio and cement content on sea water resistance of concrete", Build. Environ., vol. 42, n0 4 (2007), pp. 1770-6.

(73) Luo, R.; Cai, Y.; Wang, C.; Huang, X.: "Study of chloride binding and diffusion in GGBS concrete", Cem. Concr. Res., vol. $33, \mathrm{n}^{0} 1$ (2003), pp. 1-7.

(74) Cheng, A.; Huang, R.; Wu, J.-K.; Chen, C.-H.: "Influence of GGBS on durability and corrosion behavior of reinforced concrete", Materials Chemistry and Physics, vol. 93, n0 2-3 (2005), pp. 404-11.

(75) ASTM-C989/C989M "Standard Specification for Slag Cement for Use in Concrete and Mortars". ASTM Standars (2012).

(76) Montemor, M. F.; Cunha, M. P.; Ferreira, M. G.; Simões, A. M.: "Corrosion behaviour of rebars in fly ash mortar exposed to carbon dioxide and chlorides", Cem. Concr. Comp., vol. 24, n 1 (2002), pp. 45-53.

(77) Choi, Y.-S.; Kim, J.-G.; Lee, K.-M.: "Corrosion behavior of steel bar embedded in fly ash concrete", Corrosion Science, vol. $48, \mathrm{n}^{0} 7$ (2006), pp. 1733-45.

(78) Dhir, R. K.; Jones, M. R.: "Development of chloride-resisting concrete using fly ash", Fuel, vol. 78, n 2 (1999), pp. $137-42$. 
(79) Ampadu, K. O.; Torii, K.; Kawamura, M.: "Beneficial effect of fly ash on chloride diffusivity of hardened cement paste", Cem. Concr. Res., vol. 29, n0 4 (1999), pp. 585-90.

(80) Boğa, A. R.; Topçu, İ. B.: "Influence of fly ash on corrosion resistance and chloride ion permeability of concrete", Constr. Build. Mater., vol. 31, nº 0 (2012), pp. 258-64.

(81) Aponte, D. F.; Barra, M.; Vàzquez, E.: "Durability and cementing efficiency of fly ash in concretes", Constr. Build. Mater., vol. 30, n० 0 (2012), pp. 537-46.

(82) Nath, P.; Sarker, P.: "Effect of Fly Ash on the Durability Properties of High Strength Concrete", Procedia Engineering, vol. 14, n 0 (2011), pp. 1149-56.

(83) Diana, B.; Daniela, Á.; Mejía, R.: "Durabilidad de morteros adicionales con cenizas volantes de alto contenido de carbón", Rev LatinAm Metal Mater, vol. 32, $\mathrm{n}^{0} 1$ (2012), pp. 61-70.

(84) Khunthongkeaw, J.; Tangtermsirikul, S.; Leelawat, T.: "A study on carbonation depth prediction for fly ash concrete", Constr. Build. Mater., vol. 20, n0 9 (2006), pp. 744-53.

(85) Shi, H.-s.; Xu, B.-w.; Zhou, X.-c.: "Influence of mineral admixtures on compressive strength, gas permeability and carbonation of high performance concrete", Constr. Build. Mater., vol. 23, n 5 (2009), pp. 1980-5.

(86) Ding, Q.; Geng, J.; Hu, S.; Sun, J.; Sun, B.: "Different effects of fly ash and slag on anti-rebar corrosion ability of concrete with chloride ion", Wuhan Univ J Nat Sci, vol. 14, n0 4 (2009), pp. 355-61.

(87) ASTM-C618 "Standard Specification for Coal Fly Ash and Raw or Calcined Natural Pozzolan for Use in Concrete". ASTM Standards (2012).

(88) Abo-El-Enein, S. A.; Abbas, R.; Ezzat, E.-S.: "Propiedades y durabilidad de los cementos adicionados con metacaolín", Mater. Construcc., vol. 60, n० 299 (2010), pp. 21-35.

(89) Sabir, B. B.; Wild, S.; Bai, J.: "Metakaolin and calcined clays as pozzolans for concrete: a review", Cem. Concr. Comp., vol. 23, $\mathrm{n}^{0}$ 6 (2001), pp. 441-54.

(90) Siddique, R.; Klaus, J.: "Influence of metakaolin on the properties of mortar and concrete: A review", Applied Clay Science, vol. 43, nO 3-4 (2009), pp. 392-400.

(91) Batis, G.; Pantazopoulou, P.; Tsivilis, S.; Badogiannis, E.: "The effect of metakaolin on the corrosion behavior of cement mortars", Cem. Concr. Comp., vol. 27, no 1 (2005), pp. 125-30.

(92) Parande, A. K.; Ramesh Babu, B.; Aswin Karthik, M.; Deepak Kumaar, K. K.; Palaniswamy, N.: "Study on strength and corrosion performance for steel embedded in metakaolin blended concrete/mortar", Constr. Build. Mater., vol. 22, n 3 (2008), pp. 127-34.

(93) Gutiérrez, R. M. d.; Delvasto, S.; Talero, R.: "Una nueva puzolana para materiales cementicios de elevadas prestaciones", Mater. Construcc., vol. 50, n0 260 (2000), pp. 5-13.

(94) Courard, L.; Darimont, A.; Schouterden, M.; Ferauche, F.; Willem, X.; Degeimbre, R.: "Durability of mortars modified with metakaolin", Cem. Concr. Res., vol. 33, no 9 (2003), pp. 1473-9.

(95) Poon, C. S.; Kou, S. C.; Lam, L.: "Compressive strength, chloride diffusivity and pore structure of high performance metakaolin and silica fume concrete", Constr. Build. Mater., vol. 20, n 10 (2006), pp. 858-65.

(96) Bai, J.; Wild, S.; Sabir, B. B.: "Sorptivity and strength of air-cured and water-cured PC-PFA-MK concrete and the influence of binder composition on carbonation depth", Cem. Concr. Res., vol. 32, n 11 (2002), pp. 1813-21.

(97) Kim, H.-S.; Lee, S.-H.; Moon, H.-Y.: "Strength properties and durability aspects of high strength concrete using Korean metakaolin", Constr. Build. Mater., vol. 21, no 6 (2007), pp. 1229-37.

(98) Mejía, R.; Rodríguez, C.; Rodríguez, E.; Torres, J.; Delvasto, S.: "Concreto adicionado con metacaolín: Comportamiento a carbonatación y cloruros", RevFacIngUnivAntioquia, vol. 48, n (2009), pp. 55-64.

(99) Vejmelková, E.; Pavlíková, M.; Keppert, M.; Keršner, Z.; Rovnaníková, P.; Ondráček, M.; Sedlmajer, M.; Černý, R.: "High performance concrete with Czech metakaolin: Experimental analysis of strength, toughness and durability characteristics", Constr. Build. Mater., vol. 24, n0 8 (2010), pp. 1404-11.

(100) Siddique, R.; Iqbal Khan, M. Rice Husk Ash, Supplementary Cementing Materials, Springer Berlin Heidelberg, 231-81 (2011).

(101) Gastaldini, A. L. G.; Isaia, G. C.; Saciloto, A. P.; Missau, F.; Hoppe, T. F.: "Influence of curing time on the chloride penetration resistance of concrete containing rice husk ash: A technical and economical feasibility study", Cem. Concr. Comp., vol. 32 , no 10 (2010), pp. 783-93.

(102) Madandoust, R.; Ranjbar, M. M.; Moghadam, H. A.; Mousavi, S. Y.: "Mechanical properties and durability assessment of rice husk ash concrete", Biosystems Engineering, vol. 110, n 2 (2011), pp. 144-52.

(103) Nehdi, M.; Duquette, J.; El Damatty, A.: "Performance of rice husk ash produced using a new technology as a mineral admixture in concrete", Cem. Concr. Res., vol. 33, n0 8 (2003), pp. 1203-10.

(104) Chindaprasirt, P.; Rukzon, S.: "Strength, porosity and corrosion resistance of ternary blend Portland cement, rice husk ash and fly ash mortar", Constr. Build. Mater., vol. 22, n0 8 (2008), pp. 1601-6.

(105) Chatveera, B.; Lertwattanaruk, P.: "Durability of conventional concretes containing black rice husk ash", Journal of Environmental Management, vol. 92, n0 1 (2011), pp. 59-66.

(106) Cizer, O.; Balen, K. V.; Elsen, J.; Gemert, D. V. "Carbonation and hydration of calcium hydroxide and calcium silicate binders with rice husk ash ". 2nd International Symposium on Advances in Concrete through Science and Engineering Quebec (2006). 
(107) Kroehong, W.; Sinsiri, T.; Jaturapitakkul, C.; Chindaprasirt, P.: "Effect of palm oil fuel ash fineness on the microstructure of blended cement paste", Constr. Build. Mater., vol. 25, n 11 (2011), pp. 4095-104.

(108) Jaturapitakkul, C.; Kiattikomol, K.; Tangchirapat, W.; Saeting, T.: "Evaluation of the sulfate resistance of concrete containing palm oil fuel ash", Constr. Build. Mater., vol. 21, n0 7 (2007), pp. 1399-405.

(109) Megat Johari, M. A.; Zeyad, A. M.; Muhamad Bunnori, N.; Ariffin, K. S.: "Engineering and transport properties of high-strength green concrete containing high volume of ultrafine palm oil fuel ash", Constr. Build. Mater., vol. 30, $\mathrm{n}^{0} 0$ (2012), pp. 281-8.

(110) Shi, C.; Wu, Y.; Riefler, C.; Wang, H.: "Characteristics and pozzolanic reactivity of glass powders", Cem. Concr. Res., vol. $35, n^{0} 5$ (2005), pp. 987-93.

(111) Shayan, A.; Xu, A.: "Value-added utilisation of waste glass in concrete", Cem. Concr. Res., vol. 34, no 1 (2004), pp. 81-9. (112) Shao, Y.; Lefort, T.; Moras, S.; Rodriguez, D.: "Studies on concrete containing ground waste glass", Cem. Concr. Res., vol. 30, no 1 (2000), pp. 91-100.

(113) Shi, C.; Zheng, K.: "A review on the use of waste glasses in the production of cement and concrete", Resources, Conservation and Recycling, vol. 52, n0 2 (2007), pp. 234-47.

(114) Matos, A. M.; Sousa-Coutinho, J.: "Durability of mortar using waste glass powder as cement replacement", Constr. Build. Mater., vol. 36, n० 0 (2012), pp. 205-15.

(115) Payá, J.; Borrachero, M. V.; Monzó, J.; Soriano, L.: "Estudio del comportamiento de diversos residuos de catalizadores de craqueo catalítico (FCC) en cemento Portland", Mater. Construcc., vol. 59, nº 296 (2009), pp. 37-52.

(116) Zornoza, E.; Garcés, P.; Payá, J.: "Estudio de la velocidad de corrosión de aceros embebidos en morteros de cemento sustituidos con residuo de catalizador de craqueo catalítico (FC3R)", Mater. Construcc., vol. 58, no 292 (2008), pp. 27-43.

(117) Ramírez-Arellanes, S.; Cano-Barrita, P. F. d. J.; Julián-Caballero, F.; Gómez-Yañez, C.: "Propiedades de durabilidad en concreto y análisis microestructural en pastas de cemento con adición de mucílago de nopal como aditivo natural", Mater. Construcc., vol. $62, \mathrm{n}^{0}$ 307 (2012), pp. 327-41.

(118) Ahmad, Z. Chapter 12 - Concrete Corrosion, Principles of Corrosion Engineering and Corrosion Control, Butterworth-Heinemann, Oxford, pp. 609-46 (2006).

(119) Wilson, K.; Jawed, M.; Ngala, V.: "The selection and use of cathodic protection systems for the repair of reinforced concrete structures", Constr. Build. Mater., vol. 39 (2013), pp. 19-25

(120) Lourenço, Z.: "Protecção catódica de estruturas de betão armado", Corros Prot Mater, vol. 26, n0 3 (2007), pp. 79-85.

(121) Bertolini, L.; Bolzoni, F.; Pedeferri, P.; Lazzari, L.; Pastore, T.: "Cathodic protection and cathodic preventionin concrete: principles and applications", Journal of Applied Electrochemistry, vol. 28, n0 12 (1998), pp. 1321-31.

(122) Redaelli, E.; Bertolini, L.: "Electrochemical repair techniques in carbonated concrete. Part II: cathodic protection", Journal of Applied Electrochemistry, vol. 41, n⿳0 7 (2011), pp. 829-37.

(123) Christodoulou, C.; Glass, G.; Webb, J.; Austin, S.; Goodier, C.: "Assessing the long term benefits of Impressed Current Cathodic Protection", Corrosion Science, vol. 52, n0 8 (2010), pp. 2671-9.

(124) Fu, X.; Chung, D. D. L.: "Carbon fiber reinforced mortar as an electrical contact material for cathodic protection", Cem. Concr. Res., vol. 25, n0 4 (1995), pp. 689-94.

(125) Hou, J.; Chung, D. D. L.: "Cathodic protection of steel reinforced concrete facilitated by using carbon fiber reinforced mortar or concrete", Cem. Concr. Res., vol. 27, n0 5 (1997), pp. 649-56.

(126) Xu, J.; Yao, W.: "Current distribution in reinforced concrete cathodic protection system with conductive mortar overlay anode", Constr. Build. Mater., vol. 23, no 6 (2009), pp. 2220-6.

(127) Jing, X.; Wu, Y.: "Electrochemical studies on the performance of conductive overlay material in cathodic protection of reinforced concrete", Constr. Build. Mater., vol. 25, nº 5 (2011), pp. 2655-62.

(128) Darowicki, K.; Orlikowski, J.; Cebulski, S.; Krakowiak, S.: "Conducting coatings as anodes in cathodic protection", Progress in Organic Coatings, vol. 46, n0 3 (2003), pp. 191-6.

(129) Orlikowski, J.; Cebulski, S.; Darowicki, K.: "Electrochemical investigations of conductive coatings applied as anodes in cathodic protection of reinforced concrete", Cem. Concr. Comp., vol. 26, n0 6 (2004), pp. 721-8.

(130) Moreno, A. d. V.; Torres, A.; Terán, J.; Pérez, J. T.; Oidor, P.: "Protección catódica de concreto reforzado usando ánods de sacrificio discretos ", Instituto Mexicano del Transporte, vol. 290, n (2006), pp. 1-60.

(131) Tróconis, O.; Contreras, D.; Sánchez, M.; Fernández, M.; Bravo, J.; Morón, O.; Vezga, C.; Fernández, R.; Navarro, A.; Sarcos, A.: "Evaluación/Rehabilitación de estructuras en ambientes marinos. Caso historico: Puente de Maracaibo", Corros Prot Mater, vol. 25, $\mathrm{n}^{0}$ 3 (2006), pp. 74-91.

(132) Parthiban, G. T.; Parthiban, T.; Ravi, R.; Saraswathy, V.; Palaniswamy, N.; Sivan, V.: "Cathodic protection of steel in concrete using magnesium alloy anode", Corrosion Science, vol. 50, no 12 (2008), pp. 3329-35.

(133) Burns, W. R.; Daily, S.: "Cathodic protection os a costal brigde in texas using a thermally sprayed aluminum alloy", NACE Corrosion 2004, vol. 04338, n (2004).

(134) Ip, A. K. C.; Pianca, F.: "Applications of sacrificial anode cathodic protection systems for highway bridges - Ontario experience. ", NACE Corrosion 2002, vol. 02267, $\mathrm{n}^{0}$ (2002). 
(135) Whitmore, D.: "New Developments in the Galvanic Cathodic Protection of Concrete Structures", NACE Corrosion 2004, vol. 04333, $\mathrm{n}^{0}$ (2004).

(136) Bertolini, L.; Gastaldi, M.; Pedeferri, M.; Redaelli, E.: "Prevention of steel corrosion in concrete exposed to seawater with submerged sacrificial anodes", Corrosion Science, vol. 44, n' 7 (2002), pp. 1497-513.

(137) Sergi, G.; Whitmore, D.: "Performance of zinc sacrificial anodes for long-term control of reinforcement corrosion", NACE Corrosion 2010, vol. n (2010).

(138) Pedeferri, P.: "Cathodic protection and cathodic prevention", Constr. Build. Mater., vol. 10, n0 5 (1996), pp. 391-402.

(139) Bertolini, L.; Bolzoni, F.; Gastaldi, M.; Pastore, T.; Pedeferri, P.; Redaelli, E.: "Effects of cathodic prevention on the chloride threshold for steel corrosion in concrete", Electrochimica Acta, vol. 54, nº 5 (2009), pp. 1452-63.

(140) Sánchez, M. J.: Extracción electroquímica de cloruros del hormigón armado: estudio de diferentes variables que influyen en la eficiencia del tratamiento, Universidad de Alicante, Alicante (2004).

(141) Barreto, E. C.: Avaliação do método de extração eletroquímica de cloretos para reabilitação de estruturas de concreto com problemas de corrosão das armaduras., Escola Politécnica da Universidade de São Paulo, São Paulo (2002).

(142) Bertolini, L.; Bolzoni, F.; Elsener, B.; Pedeferri, P.; Andrade, C.: "La realcalinización y la extracción electroquímica de los cloruros en las construcciones de hormigón armado", Mater. Construcc., vol. 46, nº 244 (1996), pp. 45-55.

(143) Sánchez, M.; Garcés, P.; Climent, M.: "Extracción electroquímica de cloruros del hormigón armado: estudio de diferentes variables que influyen en la eficiencia del tratamiento", Mater. Construcc., vol. 56, n 284 (2006), pp. 17-26.

(144) Orellan, J. C.; Escadeillas, G.; Arliguie, G.: "Electrochemical chloride extraction: efficiency and side effects", Cem. Concr. Res., vol. 34, n⿳0 2 (2004), pp. 227-34.

(145) Abdelaziz, G. E.; Abdelalim, A. M. K.; Fawzy, Y. A.: "Evaluation of the short and long-term efficiencies of electro-chemical chloride extraction", Cem. Concr. Res., vol. 39, no 8 (2009), pp. 727-32.

(146) Rodríguez, S. L.; Miranda, J. M.; Tiburcio, G.; Narváez, L.; Hernández, L. S.: "State of corrosion of rebars embedded in mortar specimens after an electrochemical chloride removal", Portugaliae Electrochimica Acta, vol. 28, n 3 (2010), pp. 153-64.

(147) Fajardo, G.; Escadeillas, G.; Arliguie, G.: "Electrochemical chloride extraction (ECE) from steel-reinforced concrete specimens contaminated by "artificial" sea-water", Corrosion Science, vol. 48, n 1 (2006), pp. 110-25.

(148) Orellan Herrera, J. C.; Escadeillas, G.; Arliguie, G.: "Electro-chemical chloride extraction: Influence of C3A of the cement on treatment efficiency", Cem. Concr. Res., vol. 36, n 10 (2006), pp. 1939-46.

(149) Elsener, B.; Angst, U.: "Mechanism of electrochemical chloride removal", Corrosion Science, vol. 49, n0 12 (2007), pp. 4504-22. (150) Yeih, W.; Chang, J. J.; Hung, C. C.: "Selecting an adequate procedure for the electrochemical chloride removal", Cem. Concr. Res., vol. 36, n० 3 (2006), pp. 562-70.

(151) Monteiro, E.; Helene, P.; Barbosa, P.: "Evaluación del método de extracción electroquímico de cloruros para la rehabilitación de estructuras de hormigón dañadas por corrosión de la armadura", Mater. Construcc., vol. 53, n 271-272 (2003), pp. 91-100.

(152) Miranda, J. M.; Cobo, A.; Otero, E.; González, J. A.: "Limitations and advantages of electrochemical chloride removal in corroded reinforced concrete structures", Cem. Concr. Res., vol. 37, n0 4 (2007), pp. 596-603.

(153) Sánchez, M.; Alonso, M. C.: "Electrochemical chloride removal in reinforced concrete structures: Improvement of effectiveness by simultaneous migration of calcium nitrite", Constr. Build. Mater., vol. 25, no 2 (2011), pp. 873-8.

(154) Pérez, A.; Climent, M. A.; Garcés, P.: "Electrochemical extraction of chlorides from reinforced concrete using a conductive cement paste as the anode", Corrosion Science, vol. 52, n0 5 (2010), pp. 1576-81.

(155) Ribeiro, P. H. L. C.: Realcalinização eletroquímica de estruturas de concreto armado carbonatadas inseridas no meio urbano:influência de características da estrutura no comportamento do tratamento, Universidade Federal da Paraíba, João Pessoa (2009).

(156) Banfill, P. F. G.: "Re-alkalisation of carbonated concrete - Effect on concrete properties", Constr. Build. Mater., vol. 11, no 4 (1997), pp. 255-8.

(157) Yeih, W.; Chang, J. J.: "A study on the efficiency of electrochemical realkalisation of carbonated concrete", Constr. Build. Mater., vol. 19, n० 7 (2005), pp. 516-24.

(158) Redaelli, E.; Bertolini, L.: "Electrochemical repair techniques in carbonated concrete. Part I: electrochemical realkalisation", Journal of Applied Electrochemistry, vol. 41, $\mathrm{n}^{0} 7$ (2011), pp. 817-27.

(159) Araújo, W. C. d.: Estudo da repassivação da armadura em concretos carbonatados através da técnica de realcalinização química, Universidade de São Paulo, São Paulo (2009).

(160) González, F.: Realcalinización Electroquímica del Concreto Reforzado Carbonatado: Una opción de prevención contra la corrosión, Universidad Autónoma de Nuevo León y Université Paul Sabatier, San Nicolás de la Garza (2010).

(161) Tong, Y.; Bouteiller, V.; Marie-Victoire, E.; Joiret, S.: "Efficiency investigations of electrochemical realkalisation treatment applied to carbonated reinforced concrete - Part 1: Sacrificial anode process", Cem. Concr. Res., vol. 42, no 1 (2012), pp. 84-94.

(162) Carvajal, A. M.; Acuña, A.; Acuña, F.; Herrera, A.; Vera, R.: "Estudio sobre un método de recuperación de hormigones carbonatados: proceso de realcalinización", Revista de la Construcción, vol. 4, no 1 (2005), pp. 35-40.

(163) Miranda, J. M.; Otero, E.; González, J. A.: "Reflexiones sobre los métodos electroquímicos de rehabilitación de las estructuras corroídas de hormigón armado", Revista de Metalurgia, vol. 41, nº (2005), pp. 274-8. 